\title{
THE PREREQUISITES AND EFFECTS OF RESALE PRICE MAINTENANCE
}

WARD S. BOWMAN, JR.†

$\mathrm{P}$ RESENT IAW PERMITS the makers of most identifiable products to fix the prices at which these products may be resold (or below which they may not be resold) in most states in the United States. This is permissible on goods which are in free and open competition with other goods of the same general class, ${ }^{1}$ and no agreements among competing sellers at any level are sanctioned. ${ }^{2}$ These "safeguards" to competition provide the basis for the contention that the fair-trade laws do not eliminate competition or raise prices. The opposing view is that competition is as important in distribution as in manufacturing, and that dealer competition is inevitably eliminated. Consumers are thus limited in the range of choices they may exercise with respect to service facilities, convenience, or price in the sale of price-maintenance products.

The makers of many products maintain prices for resale; most do not. Many producers who maintain prices on some of their products do not do so on others. A great many reasons have been offered to explain why resale prices are set.

Part I of this article is an attempt to set out the conditions under which resale price maintenance has been used, and the objectives which are sought to be obtained by its use, first by dealers, then by manufacturers, and finally by combinations of both. The compatibility of these conditions and objectives is then related to "free and open competition." Part II is concerned with empirical evidence on the effects of resale price maintenance. Included is new information which has been secured on dentifrice prices in fair-trade and non-fair-trade states covering the period January, 1951 to January, 1953.

† Research Associate (Associate Professor), University of Chicago Law School.

${ }^{1}$ The provision is contained in both the Miller-Tydings Act and the McGuire Act. 50 Stat. 693 (1937), 15 U.S.C.A. $\$ 1$ (1951); 66 Stat. 632 (1952), 15 U.S.C.A. \$45 (Supp., 1952).

${ }^{2}$ Ibid. 


\section{Conditions under Which Resale Price MaInTenance Is Utilized}

\section{A. Dealer Sponsorship}

The early use of resale price maintenance in the drug trade in the United States, in Great Britain, and in France indicates the importance of dealer organization and pressure for the establishment of a system of resale price maintenance.

Price maintenance in drugs in the United States was inaugurated as wholesale price maintenance in 1876. In that year an association of western drug wholesalers was formed which was the predecessor of the National Wholesale Druggists' Association (formed in 1882). This association was formed for the purpose of dealing with the problem of "excessive" competition among wholesalers. ${ }^{3}$

One of the urgent problems facing the new association was "enticing away or dissatisfying the customers of others" and "making what are called 'leaders' in the trade." From the beginning, the wholesale druggists' association, to solve the loss-leader problem, sponsored what came to be the established method of marketing proprietaries-the manufacturer would set the wholesale price and allow a discount to be deducted upon remittance by wholesalers. This plan, known as the "Rebate Plan," was sponsored by the wholesalers and presented to the manufacturers for adoption. The plan was a resale price-maintenance arrangement; the manufacturers were to pay back to wholesalers at regular intervals a stipulated percentage of the initial price on condition that scheduled prices had been maintained. ${ }^{5}$ It was recognized that there were disadvantages to manufacturers in carrying out a resale price-maintenance plan. Manufacturers insisted that the wholesalers agree not to sell any imitations or close substitutes of the preparations of the manufacturers signing the agreement. ${ }^{\mathbf{B}}$

Early attempts by retailers to gain the same protection from competition which resale price maintenance was thought to provide for the drug wholesalers were unsuccessful. The wholesalers in 1884 did not react favorably to the retailers' request for protection against price competition. They resisted in much the same manner as did the manufacturers when the wholesalers had made a similar request of their sup-

${ }^{3}$ National Wholesale Druggists' Ass'n, A History of the National Wholesale Druggists' Association 19 (1924).

Ibid., at 30 .

${ }^{5}$ Ibid.

Ibid., at 34. 
pliers. Moreover, wholesalers considered the retailers' plan impracticable because of the large number of retailers. ${ }^{7}$ Price maintenance at the retail level was tried by a few manufacturers in the 1880 's, ${ }^{8}$ although it did not then succeed and was temporarily abandoned in $1885 .^{\circ}$

In 1900 a tripartite agreement between the retailers, wholesalers, and manufacturers was reached. This agreement contained the following conditions insisted upon by the manufacturers: jobbers were to (1) refrain from disparaging proprietary goods, (2) ask no further discounts from manufacturers than then allowed, (3) discontinue their preparation of substitutes for the manufacturers' products, and (4) refrain from selling proprietary preparations, at any price, to aggressive cutters or brokers. ${ }^{10}$ Reference to discontinuance by jobbers of their own substitute preparations suggests that these preparations were making inroads on proprietary products. The manufacturers wanted assurances concerning this form of competition. Moreover, apprehension existed among both manufacturers and wholesalers about extending resale price maintenance to the retail level. It is notable that an "aggressive cutter" had to be so designated by seventy-five per cent of the local trade. Such a provision permitted both manufacturers and wholesalers to make substantial sales to retailers in areas where pricecutting was typical.

Despite continuing doubt on the part of wholesalers and manufacturers concerning the effectiveness or the desirability of retail organization, retailers in the drug business exerted increasing influence after 1900. By 1904, when the legality of the tripartite agreement was being challenged in the courts, it was stated that the drug retailers had already been successful in "advancing and making uniform the prices for prescriptions; having proprietors refuse to patronize newspapers where cut prices were advertised; and doing away with the necessity for a special request from local retail associations, in order to have wholesalers refuse to sell to aggressive cutters."11

In Great Britain, as in the United States, the drug distributors played a predominant role in establishing control over resale price. The Pro-

\footnotetext{
'One critic of the retailers' plan, Mr. Crittenton, thought the plan an absurdity and remarked that it might be made to work only in small cities or towns having not more than a dozen retail stores. Ibid., at 36 .

${ }^{8}$ Ibid., at 35.

Ibid., at 36 .

${ }^{10}$ Jayne v. Loder, 149 Fed. 21, 24 (C.A. 3d, 1906).

${ }^{11}$ Ibid., at 26.
} 
prietary Articles Trade Association (PATA), dealing in proprietary medicinal, veterinary, toiletry, and perfumery preparations, claims to be the first British organization to deal with price-cutting on a national scale. It was formed in 1896 when price-cutting in Great Britain on proprietary pharmaceuticals was widespread..$^{12}$

In 1895 Sir William Glyn-Jones, who at that time was a retail pharmacist, had started his own newspaper, The Anti-Cutting Record, in which he first formulated his plan for ending price-cutting and "substitution"- - getting the customer to buy a "just-as-good" product on which the retailer received a more satisfactory margin. ${ }^{13}$ It was considered essential that the three interested parties-manufacturer, wholesaler, and retailer-should cooperate, and that the initiative should be taken by the retailer. ${ }^{14}$

Securing a wide coverage of retailers presented difficulties in Great Britain, as in the United States. Because of the apathetic attitude of retailers it was difficult to achieve full representation of this branch of the trade. As a result, obtaining cooperation from manufacturers was made more difficult because of the danger of offending important customers. ${ }^{15}$ Other evidence indicates that the manufacturers, for other reasons, were also something less than enthusiastic. ${ }^{16}$ The manufacturers of brands which had obtained consumer acceptance through extensive advertising exhibited no eagerness to join the scheme; they took account of the likely effects of increased prices on their sales. ${ }^{17}$ Moreover, the pre-packaged articles of these manufacturers were handled more efficiently by outlets other than the relatively specialized chemist shops. The entry of new retail outlets handling these items was made easier. ${ }^{18}$ These other retail outlets, which also opposed resale price maintenance, could utilize relatively unskilled labor for the simplified task of selling this pre-packaged merchandise. These factors tended to increase the amount of competition at retail but was not a situation

\footnotetext{
${ }^{12}$ British Board of Trade, Report of the Committee on Resale Price Maintenance 40 (1949).

${ }^{13}$ Tbid. Proprietary lines formed about one half of the turnover of the average retail chemist at this time.

${ }^{14}$ A similar tripartite arrangement operated in the United States in the early 1900's. See note 10 supra.

${ }^{15}$ Op. cit. supra n. 12.

${ }^{10}$ See Yamey, Origins of Resale Price Maintenance, 62 Econ. Journal 522 (1952).

${ }^{17}$ They also wanted to be assured that if they adopted resale price maintenance their competitors would do likewise. Tbid., at 535.

${ }^{18}$ Ibid., at 524.
} 
which necessarily caused concern for the manufacturers. Those who considered themselves the "legitimate" dealers were the ones who found this condition particularly troublesome.

Retailers' organizations in Great Britain favoring resale price maintenance had a very difficult time persuading the manufacturers of proprietary articles that the plan was in the manufacturers' interest; the arguments were not convincing until the organizations represented a large number of retailers. ${ }^{19}$ Solidarity of action on the part of the retailers was essential, and this meant, according to Glyn-Jones, the power effectively to boycott a manufacturer's goods. ${ }^{20}$

After reviewing the trade literature in Great Britain during the period 1895 to 1906, Yamey reaches unequivocal conclusions about the origins of resale price maintenance there. The role of the drug trade was particularly important but his conclusions are not limited to this field. As Yamey put it,

First, the initiative to introduce resale price maintenance did not come from the manufacturers, the great majority of whom were reluctant to move in the matter. Secondly, the pace at which the reluctance of manufacturers was overcome depended largely upon the strength of retail organisation. Thirdly, the most effective resistance to the introduction of protected prices came from the owners of wellestablished brands. 21

Resale price maintenance in the drug industry in France was initiated because of cut-price competition in the distribution of proprietary drug specialities. ${ }^{22}$ In France, as in the United States and Great Britain, price maintenance in drugs was sponsored by resellers, not producers. The dominant role was played by the retailers.

Prior to the 1850's drugs were typically prepared by the druggist who dealt with the ultimate consumer. By 1875 it is estimated that fifteen per cent of the sales of retail druggists in France involved products which were made by manufacturing firms and sold under the manufacturer's trade name. ${ }^{23}$ Competition among retailers became especially severe in the sale of these specialties.

Organization of retailers for the purpose of attempting to control the resale price of proprietary pharmaceuticals first occurred among the druggists of Versailles in $1886 .{ }^{24}$ In that year they signed an accord that they would not sell specialty products at more than ten per cent below

\footnotetext{
18 Ibid., at 529.

${ }^{20}$ Ibid., at 530 .

21 Ibid., at 540.

* Barret, Histoire du Développement de la Politique aes Prix imposés en France 7, 8 (Paris, 1935).

${ }^{25}$ Ibid., at 9.

${ }^{2}$ Ibid., at 11.
} 
the suggested prices posted on the products by the manufacturers. Sporadic and localized efforts of this kind were not at the time particularly important or typical. Relatively few products were involved. Moreover, particularly in the larger cities, there was after 1880 a rather rapid growth of large commercial drugstores. These stores, as contrasted to the small pharmacies, which were typically owned and operated by individuals, relied on quantity sales, high turnover, and low prices-prices often substantially below list on proprietary items.

At a national convention of druggists in $1898^{25}$ delegates passed a motion to suppress drug specialties. By 1903 a majority of druggists declared themselves in favor of a resale price-maintenance plan for pharmaceutical specialties. ${ }^{26}$

French dealers in pharmaceuticals found it difficult to achieve the necessary co-operation of the manufacturers, ${ }^{27}$ but eventually a number of different systems of supervising resale prices were adopted by the pharmaceutical manufacturers. ${ }^{28}$ By 1933 practically all French drug stores were participating in a system enforced by means of contractual sanctions imposed by a strong national association of dealers on the one side and a national association of producers on the other.

The foregoing examples suggest that resale price maintenance is a method used by organized dealers to force unwilling manufacturers to work for them to protect dealer profit margins. ${ }^{29}$ This is a simple,

${ }^{25}$ In 1885 a society of chemists had been formed in a sector of Paris for the purpose of combating price-cutting. By December 1893 this society had expanded and became a general association of French drug stores, the Syndicat Général des Pharmacies de France. Ibid., at 23.

28 Thid., at 22 .

${ }^{27}$ In 1899 the first producer group contained just six pharmaceutical manufacturers. Reimbursements of twenty per cent of list price were offered to dealers only on condition that resale prices were not cut. Ibid., at 38. By 1904 there were 45 members in the producers' association. Reimbursements in that year amounted to something over one million francs. Ibid., at 42. In 1907 there were 56 members in the producers' association. By 1913 there were 220 . Ibid., at 70 .

Out of a total of ten thousand druggists in 1910, five thousand were members of the retail druggist group. Ibid., at 86 .

${ }^{23}$ Some used rebate certificates, some used premiums, and some simple declarations. In December 1907, all the producers applying any of the various kinds of price-maintenance schemes were brought together in a single association: Syndicat général de la réglementation des produits pharmaceutiques ou hygiéniques-spécialisés par des marques de fabrique. Tbid., at 67 .

20 The success of dealers in achieving workable resale price maintenance has been said to be limited by an increase in non-price competition caused by the elimination of price competition. Although a guaranteed mark-up by the original seller (resale price maintenance) may create conditions favorable to entry of new lines or to additional non-price competition from existing firms in the form of greater service, these substitute forms of competition are not likely to be as effective as direct price competition in reducing dealer 
plausible explanation of resale price maintenance, and probably explains much of its recent as well as its early use. This explanation is supported by the very high proportion of "fair-trade" cases involving products the dealers of which have been organized in effective trade associations, for example, drugs, cosmetics, and liquor. The Federal Trade Commission Report on Resale Price Maintenance in 1945 also stressed the importance of dealer organization. This report quotes from the Illinois Package Liquor Review to emphasize the point:

The pressure and the moral force of the association is responsible more than any other single factor for whatever price maintenance we have in Chicago. ... With pressure and persuasion, with cajolery and threat, with pestering and pleading, by convening time and again with distillers and importers, the association officers have convinced a number of the principal firms of the folly of a continued policy of dog eat dog. ${ }^{30}$

The fact that resale price maintenance has received strong support from dealer organizations should not obscure the fact that opposition is also found among some dealers. Effective opposition to resale price maintenance has come from retail dealers whose sales policies are predicated upon high turnover, bargain prices, and limited service facilities. ${ }^{31}$ Resale price maintenance prevents this kind of merchandising of pricemaintained products.

Dealers or dealer groups sponsoring resale price maintenance must represent a fairly large proportion of the potential outlets available to a particular manufacturer. Otherwise threats or implied threats to withdraw patronage from a non-co-operating manufacturer may be resisted. Successful price maintenance in the interest of dealers may also require the co-operation of manufacturers making closely competing products. Otherwise a price-maintaining manufacturer may lose sales rapidly because of the lower retail prices available on the products of his competitors. Of course, the closer the substitute the more necessary it is that the substitute be price-maintained to prevent its sales from dissipating the assured margin on the price-maintained product. ${ }^{32}$

profits. The advantages of price-fixing schemes need not last forever, nor create perfect monopoly, in order to be profitable. A contrary conclusion would mean that price-fixing cartels are not in the interest of the participants.

${ }^{30}$ Consult FTC, Report on Resale Price Maintenance 375 (1945).

${ }^{31}$ R. H. Macy \& Co. in New York, Schwegmann Supermarkets in New Orleans, and the Grayson-Robinson chain provide examples of strong opposition to resale price maintenance among dealers.

${ }^{32}$ In those trades where price maintenance has been a goal of dealer organizations, such as drugs and liquors, most important brands are price-maintained, even though particu- 
Dealer success in protecting margins by means of resale price maintenance also may depend upon the existence of a limited number and variety of outlets through which a product can effectively be sold. Concerted action of dealers may be required, and it is more difficult with large numbers. Moreover, concerted action by dealers' organizations to force manufacturers to adopt price maintenance is illegal, ${ }^{33}$ just as is similar concerted action among manufacturers. Consequently, dealers, in attempting to organize their trade, run risks in securing the necessary co-operation, even when most dealers are in favor of price maintenance.

Thus, to achieve effective resale price maintenance, dealers must prevent competition from substitute products and from non-co-operating outlets. The ability of manufacturers to resist price maintenance would seem to depend on the relative strength of the dealers and the manufacturers. Many manufacturers, with well-established brands, or with relatively few competitors producing close substitutes, have resisted resale price maintenance as the early experience in both Great Britain and the United States indicates; but there are numerous instances in which combinations of manufacturers did not resist, where combinations of dealers and combinations of manufacturers have jointly sponsored resale price maintenance. These cases point to the danger of easy conclusions about countervailing power of manufacturers precluding resale price maintenance.

\section{B. Sponsorship of Resale Price Maintenance by Manufacturers}

Because the price received by the manufacturer is not directly affected by resale price maintenance (a manufacturer's price to the trade need be no less or no more because of price maintenance-only the resale price is controlled) and because price competition among dealers should cause more sales without lowering returns to the manufacturer, one might expect manufacturers to encourage rather than repress dealer

lar branded products are substantially differentiated. With a very large number of competing manufacturers the administrative job of getting most manufacturers to adopt resale price maintenance becomes more difficult. The existence of numerous competing producers presents an obstacle to dealer aims in much the same manner as the existence of a large number of competing firms does to a union. Consult Stigler, The Theory of Price 253 (1952): "Until a large number of enterprises are unionized, the union has little power to raise wages. If there are many firms there are usually many new firms, so unionization is a continuous task."

${ }^{83}$ See United States v. Frankfort Distilleries, Inc., 324 U.S. 293 (1945). 
competition. Indeed, this is actually the position taken by many manufacturers upon whom dealer pressure for fixed margins is exerted. ${ }^{34}$ No manufacturer can be expected to favor the equivalent of a retailing tax levied on his product. The fact remains, however, that a great many manufacturers actively support resale price maintenance, ${ }^{35}$ even though their dealers are not organized to present the kind of united front found among drug and liquor dealers. Among the numerous explanations of sponsorship by manufacturers of resale price maintenance are (1) the protection of manufacturers' good will, (2) the maximization of returns from advertising, (3) the creation of product differentiation in order to prevent competition from substitutes, (4) the protection from the elimination of retail outlets through loss leaders, (5) price stabilization, (6) price discrimination, and (7) assurance of dealer services required for the marketing of a product.

\footnotetext{
3t The American Fair Trade Council, an association of manufacturers favoring fair trade, strongly objects to the generalization that price maintenance is due to coercion by dealers. In July, 1951 the Council, representing a widely diversified group of industries, indicated that it did not want to be identified with fair trade by coercion. Care was taken to dissociate the position of the Council from that taken by the beverage and pharmaceutical industries. The Council claimed "a much greater volume of products under voluntary fair trade than are provided by the beverage and pharmaceutical industries." Hearings on Resale Price Maintenance before the Antitrust Subcommittee of the House Committee on the Judiciary. 82 d Cong. 2d Sess. 889 (1952). An anti-coercion resolution was adopted by the Council.

${ }^{35}$ Among the manufacturing firms sponsoring resale price maintenance through early membership in the American Fair Trade League, established in 1912, were the makers of a wide variety of well-known products, including: Victor and Edison Talking Machines, Ford and Packard motor cars, Welch's grape juice, Kellogg's corn fiakes, B.V.D.'s, Ingersoll and Hamilton watches, Beechnut products, Bissell carpet sweepers, Waterman pens, Putnam books, and many others. Johnson, Ingersoll, and Montague, Control of Resale Prices 110 (1936). Other manufacturers who supported resale price maintenance prior to and during this period included the makers of Old Dutch Cleanser [Frey \& Son, Inc. v. Cudahy Packing Co., 256 U.S. 208 (1921)]; Ghirardelli chocolate [D. Ghirardelli Co. v. Hunsicker, 164 Cal. 355 (1912)]; Standard Fashion dress patterns [Weiboldt v. The Standard Fashion Co., 80 II. App. 67 (1898)]; Oneida Community silverware [Johnson, What Is a Fair Price?, 79 Printers' Ink No. 13, at 3 (1912)]; Eastman Kodak cameras and films [United States v. Eastman Kodak Co., 226 Fed. 62 (W.D. N.Y., 1915)]; International Harvester farm implements [International Harvester Co. of America v. Commonwealth, $124 \mathrm{Ky} .543$ (1907)]; Loose-Wiles tea biscuits [Cherington, Interlocking Sales Campaign of Loose-Wiles Biscuit Company, 81 Printers' Ink No. 13, at 17 (1912)]; Clark's thread [Clark v. Frank, 17 Mo. App. 602 (1885)]; Union sewer pipe [Connolly v. Union Sewer Pipe Co., 184 U.S. 540 (1902)]; Dwight's "Cow-Brand" saleratus and soda [Walsh v. Dwight, 40 App. Div. 513, 58 N.Y. Supp. 91 (1st Dep't, 1899)]; and Keystone watch cases [United States v. Keystone Watch Case Co., 218 Fed. 502 (E.D. Pa., 1915)]. Others included makers of Gillette razors, Japalac paint, Klaxon warning signals, Prophylactic tooth brushes, Smith \& Wesson revolvers, Thermos bottles, Spaulding baseballs, Simplex pencil sharpeners, Wright \& Ditson tennis rackets, Moore push pins, and Carborundum stones, to name a few. See 79 Printers' Ink No. 13, at 3 (1912).
} 


\section{Protection of Manufacturers' Good Will}

It has been said that if a retailer cuts price and if the differentiation (that which makes the consumer prefer one particular manufacturer's product over another) is tenuous or "psychic," price-cutting will tend to shift customers from brand to brand and will thus break down the "good will" value of the mark or name which advertising has built up, wasting part of the advertising. ${ }^{36}$ Thus, if the makers of Lucky Strikes and the makers of Camels could keep their dealers from competing, the Camel smokers would be more likely to continue smoking Camels, Lucky Strike smokers Lucky Strikes, and so on, and all would be better off. There is a fatal difficulty with this explanation. Cigarette manufacturers do not find it in their interests to use resale price maintenance. In fact, cigarette manufacturers find it not at all troublesome that supermarkets and grocery chains make a large proportion of cigarette sales to customers by selling in cartons at cut prices. Nor has this kind of competition led to any noticeable diminution of cigarette advertising which stresses the unique advantages of particular brands.

In selling cigarettes at retail it is not to be expected that one major brand is cut in price while others are not. It is probably true that price cuts by dealers in cigarettes leave the relative price of the brands unaffected and do not provide incentive for customers to switch brands. It is not clear that such price-maintained products as toothpaste, toasters, or light bulbs are greatly different from cigarettes in this respect.

\section{Advertising and Resale Price Matntenance}

Of the one hundred companies having the largest national advertising expenditures in 1950, fifty utilized resale price maintenance on at least one of the products sold. ${ }^{37}$ Among the companies which do maintain prices many do so only on particular items making up a small proportion of total sales. Undoubtedly a similar diversity would be found

\footnotetext{
${ }^{38}$ Consult Galbraith, Monopoly Power and Price Rigidities, 50 Q. J. Econ. $468-70$ (1936).

${ }^{87}$ Twenty-nine of these fifty companies using price maintenance were neither in the drug or liquor industry nor sold a product or products principally through drug or liquor store outlets. Of these 29 firms, 9 were firms principally engaged in manufacturing food products, 3 were tire and rubber companies, 2 were tobacco companies, and 2 were soap companies. Op. cit. supra note 34 , at $360-61$. With one possible exception (Pillsbury Mills), all of these 16 companies principally manufacture and sell products which are not price-maintained. Such is the case with most food products, tires and cigarettes. On the other hand, a number of companies are included which are known to make use of resale price maintenance extensively. These include General Electric, Westinghouse, Electric Auto-Lite, Champion, Ronson, International Silver, and Doubleday. Ibid.
} 
among smaller firms. There appears to be no correlation between advertising expenditures and the use of resale price maintenance. The argument that advertising expenses are wasted because of the breakdown of product differentiation caused by price competition and loss leaders is dealt with elsewhere. ${ }^{38}$

\section{Product Differentiation and Substitutes}

The interest of a manufacturer in resale price maintenance is said to arise from the necessity of creating and maintaining product differentiation. Advertising of trade names, trade marks, and patents promotes differentiation. Selling and advertising expenses, unless jointly undertaken, are not likely to be great if products are undifferentiated, since the advertising of one manufacturer of a homogeneous product may produce as much advantage for his competitors as for himself. There is the possibility that the non-advertiser may get a "free ride" on the advertising and sales promotion of others. High selling costs and significant product differentiation characterize many, if not most, manufactured products, only some of which are typically price-maintained. Toothpaste is price-maintained, cigarettes are not; electric shavers are price-maintained, radios are not; spark plugs are price-maintained, tires are not. All are differentiated products with high advertising and selling costs. Product differentiation alone is not a sufficient reason for resale price maintenance.

An additional factor, sometimes specified in an effort to explain manufacturers' interest in resale price maintenance, relates to the characteristics of demand for the product. If resale price maintenance is not to be harmful to a manufacturer, the demand for the product must be such that lowered price through dealer competition will not increase sales as much as some other demand-increasing activity with which dealer price competition is incompatible.

When retail (or wholesale) dealers provide an essential part of the advertising or selling activity required to market a product, and there is no alternative method other than resale price maintenance by which dealers may be remunerated for this service, then price maintenance may be desirable to manufacturers. Professor Chamberlin has pointed up the importance of selling costs incurred to create new demand. ${ }^{30}$ Ability of particular dealers to create demand for certain products, according to Chamberlin, arises because of close relations between

${ }^{38}$ See pages $835-38$ infra.

${ }^{30}$ Chamberlin, The Theory of Monopolistic Competition 120 (6th ed., 1950). 
the dealer and his customers, and the ability of a dealer to stock and push certain products at the expense of others. A manufacturer must not leave dealer relations to price competition; dealer favors must be bought, and they must be paid for. This emphasizes the control which particular retailers can exercise over their trade. Analytically, power exerted by an individual dealer is not different from power exerted by organized dealers, a case already discussed. The amount of pressure single unorganized dealers can exert on manufacturers, however, is likely to be limited. Consequently, other alternatives may be available to manufacturers in the absence of organized boycotting. Moreover, it is in the interest of single dealers to carry widely advertised and accepted products (such as major-brand cigarettes or Coca Cola) whether or not they are price-maintained. On the other hand, manufacturers bringing new products on the market may find special dealer aids (which resale price maintenance pays for) essential to their marketing plans.

\section{LOSS LEADERS}

One of the most frequently cited reasons for a manufacturer's interest in resale price maintenance is the allegedly adverse effect of "loss-leader" sales. Many manufacturers express concern when prices are cut below the costs of efficient outlets, both because of a fear that the number of dealer outlets will be reduced and because of a fear that loss leaders will break down product differentiation and encourage substitution. It is argued that the "loss leader" is in reality a "misleader." Customers are lured into a dealer's establishment by advertised bargains; when they arrive they are sold a "just-as-good" product bringing the dealer a better margin. Price maintenance is at best only a partial solution to the misleader problem, if indeed it is any solution at all. Although price maintenance prevents "price-cutting dealers" from advertising a particular product at a bargain price, it does not prevent, but encourages, adverse price comparisons once customers are in a store. Only insofar as substitution is possible is there a misleader problem. If price maintenance increases the price discrepancy between the fair-trade product and the non-fair-trade product, substitution may be encouraged. For example, the retail sporting goods section of a large mail-order house stocks one or two nationally advertised, price-maintained rifles primarily for the purpose of adverse comparison (in terms of price and quality) with its own brand. 
If retail prices are cut to or below the cost of the most efficient outlets, sales may be concentrated through relatively few dealers. It is the fear that this will drive out all but a few dealers which is said to make price maintenance in the manufacturers' interest. In the long run, the argument goes, price-maintaining manufacturers will sell more by sales through many dealers than through few dealers even though prices are higher. This means that sales are deemed to be more responsive to convenience and service than to price. It has not been established, however, that loss leaders decrease sales. The Federal Trade Commission in its Report on Resale Price Maintenance in 1931 was unable to find examples of price cuts decreasing manufacturers' sales. ${ }^{40}$ The report states:

The Commission has been at some pains to discover instances of such price cutting which were sufficiently severe to result in permanent and material reduction of the manufacturer's volume of business, but without discovering any instances in which it could be satisfactorily shown that decreased volume was primarily due to dealer price cutting. ${ }^{41}$

The Federal Trade Commission, however, has not convinced manufacturers that they do not recognize their own interests. Even though no data confirming the fact that cut prices have reduced sales have been made available, some manufacturers stress the vital importance of a large number of outlets. The McGraw Electric Company, the maker of a well-known, price-maintained toaster, cites the following example:

[D]uring the last Christmas season [1951], we found it quite impossible to carry out our seasonal promotional plans in the San Francisco area. This was due to the deep price cutting of one chain organization. Other stores, large and small, refused to meet these extremely low prices and, of course, would not co-operate in our merchandising plans. All dealers are reluctant to participate in merchandising expenditures aimed at creating willingness to buy if some other dealer, large or small, is able to get a free ride by selling at cut prices relying on the good will and acceptance which he has not helped to create. ${ }^{42}$

The inference from this is that fewer toasters were sold in San Francisco during the Christmas holidays than if the price had not been cut by a chain store. Evidence comparing sales in San Francisco and in other areas where prices were not cut, or other evidence that the price cuts diminished sales, has not been produced.

A reduction in the number of dealers is also said to have an addi-

${ }^{10}$ FTC, 2 Report on Resale Price Maintenance 4 (1931).

4 Tbid.

${ }^{43}$ Brief in Support of H. R. 6925 for McGraw Electric Co. at 11 (1952). 
tional adverse effect on manufacturers. If unrestricted price competition will eliminate many outlets, manufacturers may find themselves at the mercy of a few powerful dealers. There is little evidence to support this argument. No single retail establishment actually does a large proportion of the business in single commodities. In large metropolitan markets such as New York City, where price-cutting is said to be most prevalent, the competition among firms which use price appeals in selling merchandise is most intense. It has never seriously been contended, for example, that R. H. Macy sells at very low prices with the purpose or with the likely result that its competitors, including such firms as Gimbel's, Bloomingdale's, Abraham \& Straus, etc., will be driven out of business, and that as a result Macy's will subsequently be in a position to raise prices and exact monopoly returns. ${ }^{43}$

\section{Stabilization of Manufacturers' Prices}

Resale price maintenance has most often arisen as a concession by manufacturers to organized distributors in exchange for other concessions by dealers to manufacturers. But even in the absence of dealer pressure, manufacturers have an interest in avoiding price competition among themselves. Although direct agreement with respect to prices is illegal, avoidance of price competition may be accomplished by a mutual recognition of the losses which might occur to all if any one manufacturer were to cut prices. Resale price maintenance, by stabilizing dealer prices, may make it less likely that manufacturers' prices are cut.

Instability of prices among dealers is said to cause uncertainty among manufacturers as to whether or not rival manufacturers are cutting prices. It is contended, therefore, that the stability which price maintenance affords to manufacturers' prices can outweigh the advantages of more active dealer competition. Moreover, it may be argued that although an agreement or an understanding among manufacturers to fix resale prices would be just as illegal as would a direct price-fixing agreement, the former does not require continued joint action for enforcement and therefore creates less risk of having a "conspiracy" established.

The notion that resale price maintenance, by stabilizing dealer prices, will make it less likely that rival manufacturers will cut their prices analogizes price competition with contagious disease. Presumably the

\footnotetext{
${ }^{4}$ It has been argued that fair-trade laws, by preventing abusive price wars, have an anti-monopoly effect. Ibid., at 14 .
} 
price competition among dealers will spread to manufacturers in the form of increased pressure for lower supply prices, resulting in price concessions. Even if the predicted effect on manufacturers' prices does not occur, suspicion can be aroused among the manufacturers that rivals are "chiseling," undermining the manufacturers" understanding.

This explanation of manufacturers' sponsorship of price maintenance is unconvincing for several reasons. An extremely tenuous arrangement or understanding among manufacturers is assumed, one which is likely to collapse at the slightest provocation. Moreover, the explanation involves an assumption that dealers have less incentive to seek and manufacturers to grant price concessions when minimum resale prices are in force than when they are not. This fails to explain why any manufacturer desiring to expand sales at the expense of other manufacturers could not do so as easily by extending lower prices to dealers who would retain the savings, as by extending lower prices to dealers who would pass them on by cutting prices.

\section{Price Discrimination}

General Electric, which produced or licensed the production of 93 per cent of the total lamp production in the early 1920's, marketed incandescent lamps under agency contracts, fixing the price and the conditions under which lamps could be sold by its dealers. ${ }^{44}$ A large percentage of the lamps produced was sold by General Electric and its licensees to large contract buyers, and the remainder were sold through a vast number of retail agents to individual consumers. ${ }^{45}$ These retail outlets performed no unique service functions. Here, if anywhere, one might have expected that the advantages of a maximum of price competition among retailers along with lower prices to consumers would have been in the interest of the patent-holding producers. There were no close substitutes for the product sold, no danger of diverted sales through loss leaders, and little opportunity for retailers to promote greater sales by non-price than by price appeals.

The explanation for this complex, price-fixing mechanism lies in

“United States v. General Electric Co., 272 U.S. 476 (1926).

${ }^{45}$ At the time the government brought its case against General Electric, only 41 per cent of total lamp sales were made through agents to domestic users; 59 per cent were made to large-contract concerns ( 22 per cent without use of agents and 37 per cent through agent distributors, including retailers). For Westinghouse, the principal licensee of General Electric, only 34 per cent of sales were made through agents to domestic customers, 36 per cent were sold without agents to large-contract concerns, and 30 per cent were sold through agents to large-contract concerns. Transcript of Record at 92, 93 (stipulation), United States v. General Electric Co., 272 U.S. 476 (1926). Each of the large-contract 
price discrimination. Lamp customers could be divided into two markets, domestic and industrial (contract sales). Successful discrimination depended on avoiding diversion either by industrial users or by distributors. As a result, each of the large contract buyers, whether he bought direct or through distributor agents, agreed that no lamp bought would be resold.

Although the facts of the General Electric case indicate that industrial lamp users were prevented by contract from reselling to others, it is not clear that resale price maintenance generally would prevent the breakdown of a discriminatory pricing scheme. Diversion by dealers also needs to be prevented. Resale price maintenance would attempt to prevent dealers from supplying domestic users at cut prices out of lower cost supplies destined for industrial users. But resale price maintenance would not eliminate the incentive for dealers to increase their margins by diverting at the maintained price. Resale price maintenance has little to do with keeping two markets separate. The danger of diversion is always a problem to a discriminating seller, but a careful policing scheme would seem to be called for irrespective of whether resale price maintenance or its equivalent is utilized.

\section{Service and Non-Service Markets}

Although knowledge about the status of competition in many distributive trades is far from precise, resale price maintenance appears to be sponsored in situations which can be described as involving monopoly power by manufacturers and competition among distributors. A single seller with a unique product, or a group of sellers, either by agreement or through price leadership, may find price maintenance essential to successful merchandising. Examples are the early manufacture of phonographs under an effective patent monopoly, ${ }^{46}$ the use

buyers, whether they bought direct or through distributor agents, agreed that no lamps bought would be resold. United States v. General Electric Co., 272 U.S. 476, 482-84 (1926).

${ }^{46}$ Phonograph manufacturers were involved in extensive price-maintenance litigation: Edison Phonograph Co. v. Kaufmann, 105 Fed. 960 (C.C. Pa., 1901) (involved agreement not to sell below list on the patented Edison phonograph in 1901); Edison Phonograph Co. v. Pike, 116 Fed. 863 (C.C. Mass., 1902) (dealer contracts containing clauses prohibiting supply of Edison phonographs, parts, records, or blanks, to any dealer not signing a price-maintenance agreement); National Phonograph Co. v. Schlegel, 128 Fed. 733 (C.A. 8th, 1904) (involving resale price maintenance on the phonograph covered by Edison Phonograph Co. patents; National Phonograph Co. was then Edison's exclusive sales agent). Victor Talking Machine Co. utilized the same kind of resale price-maintenance agreement, also based on a patent license. See Victor Talking Machine Co. v. The Fair, 123 Fed. 424 (C.A. 7th, 1903); Victor Talking Machine Co. v. Kemeny, 271 Fed. 810 
of resale price maintenance by the Ford Motor Co., ${ }^{47}$ which had a dominant position in that field, and the use of resale price maintenance as part of a campaign to introduce a new product. ${ }^{48}$ In these examples an assumption that dealers were in a position to dictate terms to the suppliers seems implausible.

These examples seem to run counter to the economic principle that a monopolist on one level (here the manufacturer) can maximize his return by setting the original price only. It would strain credulity to suggest that Ford and Victor represent cases of philanthropy to dealers. An alternative explanation is called for. Many products require dealer service and extensive selling effort. If dealers can be remunerated for this service either directly by the supplier or indirectly by the purchaser's paying a higher price, a monopoly manufacturer maximizes his return by setting the proper price on the first sale. Such services as customer credit, local advertising, dealer displays, or special sales promotions usually entail costs for which dealers may be

(C.A. 3d, 1921); Straus v. Victor Talking Machine Co., 243 U.S. 490 (1917). In the latter case two other phonograph companies filed a brief as amici curiae in support of the legality of resale price-maintenance contracts.

4T The Ford Motor Co., along with the Packard Motor Co., represented the auto industry among the original members of the American Fair Trade League. Mr. Lucking, representing the Ford Motor Co., summarized the company's experience in 1914 before the House Judiciary Committee. Hearings on Trust Legislation before the House Committee on the Judiciary, 63d Cong. 2d Sess. 767 (1914). According to Lucking there were special reasons in the automobile industry for fixing resale prices. In 1913, due to the size it had achieved, Ford established an agency system for its dealers. It was a Ford policy to see that Ford cars were sold at uniform prices within exclusive dealers' territories. This system provided a double protection for dealers and was said to be occasioned by the need for prompt and loyal service. "The relation between the Ford Motor Co. and its product is not completed when it has received the price paid by the dealer. This relation continues on during the entire life of the machine sold, and the success of that machine is regarded as of vital consequence to the company." Ibid., at 768. (The same point was made with respect to watches by Charles L. Miller, president of the Hamilton Watch Co., ibid., at 786.) In 1914, 6,000 Ford dealers were under contract obligation to stock parts for quick repairs and were entrusted with showing a purchaser "how to use, handle and conserve a car." "[T]hese things," according to Lucking, "are not done by a cut-price dealer and the car loses its reputation and Ford loses its best dealers. Hence follow dissatisfied customers, . . . loss of sales, loss of business." Ibid., at 769. An outsider can afford to cut prices when the other man has stood the expense of working up the sale. The outsider in effect gets a "free ride" on the efforts of the seller.

${ }^{2 s}$ Erlanger Bros., predecessor to the B.V.D. Co., first commercialized the idea of making summer underwear in knee drawers and coat-cut undershirts. Ibid., at 733. The idea was deemed most radical, and met with wide derision in the trade. Much missionary work was required and it was necessary even to donate garments to friends in the trade to convince them of their advantages. The task of getting jobbers and dealers to stock and push the new product was a formidable one. Protecting the dealers' margin through resale price maintenance was a part of the means by which the new product was introduced. 
directly reimbursed. ${ }^{49}$ Circumstances may arise, however, in which dealers cannot be reimbursed for essential services except through their price margins. Many products, especially new ones, the use of which requires particular knowledge or special skill, may require costly demonstrations or services by the dealer which it is not possible for the dealer to charge for directly or for the manufacturer to pay for directly. If the item sold is of such nature that a customer may get his service from a service dealer and a cut price from a non-service dealer, the manufacturer may suffer because of the elimination of service outlets. ${ }^{50}$

The usefulness of resale price maintenance to manufacturers when competitive conditions exist among dealers can best be illustrated by assuming an extreme case in which there is just one manufacturer and a large number of dealers. When all of these dealers sell in one market, a single price set by the manufacturer to the dealers will maximize his monopoly return. If, however, there is one market in which the product alone is demanded and another in which the product plus service is required, and these markets overlap so that the manufacturer cannot sell his product at different prices (lower to the service dealers than to the non-service dealers), and if a buyer needing service can procure it from a service outlet and yet purchases from a non-service outlet at a competitive price, not reflecting service cost, the manufacturer is faced with a difficult question of sales policy. Since service dealers cannot provide service without recovering its cost, the manufacturer must choose between supporting the service dealers or the non-service

\footnotetext{
${ }^{6}$ Such payments or discounts may violate the Robinson-Patman Act. 49 Stat. 1526 (1936), 15 U.S.C.A. $\$ \$ 13,13$ (a), 13(b), 21(a) (1951). This act, although generally described as an anti-discrimination statute, creates a presumption that special prices or particular allowances are "discriminatory" unless they can be accurately justified by costs [15 U.S.C.A. $\$ 13$ (b) (1951)]; even then serious risks are run if it is possible to impute an intent to monopolize from unequal prices. Consequently, some manufacturers may not wish to take the legal risks involved in making special payments to dealers even when clearly related to economic services performed by the dealers. Consult Adelman, The Consistency of the Robinson-Patman Act, 6 Stanford L. Rev. 3 (1954).

${ }^{50}$ The need for special dealer services may give rise to exclusive selling agencies under some circumstances, but resale price maintenance for most products is a better solution for manufacturers because it eliminates only dealer price competition (and not service competition). The Waterman Pen Co., for example, an early advocate of resale price maintenance, at one time felt obligated to explain why its dealers could not have exclusive franchises. Consuit Hall, As the Retailer Sees It, 76 Printers' Ink No. 12, at 8 (1912). The argument was: "'Experience shows that you could sell three or four of the successful kind [Waterman's] while endeavoring to induce a customer to purchase one of the other kind for which you might have an exclusive agency. . . . You must consider that there is really no severe competition in the selling of Waterman's Ideal fountain pens, because they must be absolutely sold at the same stipulated price by every merchant who stocks them." "Ibid., at 12 .
} 
dealers. If the reduction in total sales occasioned by forcing non-service dealers to sell at prices reflecting service costs, as under resale price maintenance, is less than the reduction in sales occasioned by the elimination of dealer service, then the setting of a minimum resale price clearly benefits the original seller. ${ }^{51}$

Describing resale price maintenance when used for the purpose of insuring dealer service as creating a "spilling-over effect"s2 suggests the possibility of a windfall return to non-service dealers. Customers requiring the service can buy the product from non-service dealers as long as free service continues to be provided by service dealers. This does not mean that non-service dealers receive a windfall return, for, assuming that competition among them will undercut the maintained price, they will receive only the competitive return.

It is impossible to estimate how much resale price maintenance is to be explained by the existence of overlapping markets. This phenomenon may be fairly common where costly technical instruction by dealers is a necessary part of a successful sales program. In addition to the examples cited, such price-maintained products as high-speed cameras, color film, optical products, and some forms of sporting equipment might well fall in this category. Moreover, it seems likely that this kind of need for resale price maintenance may exist when a product is being introduced, but that the dissemination of information to customers may eventually enlarge the non-service market so that support of the service market is no longer good policy for the manufacturer.

There are cases of sponsorship of resale price maintenance by manufacturers selling in ostensibly competitive dealer markets which remain unexplained. The long-continued insistence by the Ingersoll brothers that their famous "dollar" watch be fair-traded is an example. ${ }^{53}$ It was sold through innumerable retail outlets including drug, hardware, novelty, and cigar stores. Currently the insistence upon maintained resale prices by the makers of small electrical appliances, including such firms as Sunbeam, McGraw Electric, Westinghouse, and General Electric, remains to be explained, unless the competitiveness of distribution in these trades has been misjudged.

\footnotetext{
"Even if a monopoly manufacturer owned all outlets (service and non-service), the equivalent of resale price maintenance would be required to recover necessary service costs.

${ }^{82}$ Consult Resale Price Maintenance and the Anti-Trust Laws, U. of Chi. L. Rev. 369, 376 (1951).

s3 Johnson, Ingersoll, and Montague, Control of Resale Prices (1936).
} 


\section{Joint Sponsorship by Dealers and Manufacturers}

Resale price maintenance has been used as a part of a broader scheme involving horizontal agreements. Resale price maintenance in the American book trade indicates close co-operation among book dealers and publishers. The American Booksellers' Association was formed in June, 1901, very shortly after the formation of the American Publishers' Association in February, $1901 .^{54}$ The close proximity of the dates of organization suggests co-operative action, or at least that each group knew what the other was doing. The success of either association was said to depend upon the co-operation of the other. In this respect the situation in the book trade in America at the turn of the century was similar to that in the American drug trade under the tripartite arrangement in effect at about the same time..$^{55}$ In each case the arrangement contemplated co-operation among competitors at both the manufacturer and dealer levels.

Although the initiative for resale price maintenance appears to be strong among publishers in the United States, the strong interest of booksellers in the plan must not be discounted. The first resolution of the first meeting of the American Booksellers' Association in 1901 called for acceptance of the publishers' net price system on condition that fiction books be included under the net price system as rapidly as possible. ${ }^{56}$ The association further agreed not to keep in stock, or offer for sale after notification, the books of any publisher who did not support the net price system. ${ }^{57}$ Provision was also made for expelling members who did not abide by the fixed prices and for not dealing with other booksellers who cut prices. ${ }^{68}$ Cut-price booksellers were forced to pay full retail list price. This combination of booksellers included at least 90 per cent of all booksellers, and the pubishers' association included a large proportion of publishers. ${ }^{59}$

A number of other cases of what appear to be manufacturers' sponsorship of resale price maintenance prior to and during the early 1900's coupled resale price maintenance with plans to eliminate or diminish competition among manufacturers. The resale price maintenance pro-

Bs Bobbs-Merrill Co. v. Straus, 139 Fed. 155, 158 (C.C. N.Y., 1905).

${ }^{55}$ Op. cit. supra note 10.

${ }^{50}$ Bobbs-Merrill Co. v. Straus, 139 Fed. 155, 160 (C.C. N.Y., 1905).

${ }^{57}$ Straus v. American Publishers' Ass'n., 85 App. Div. 446, 83 N.Y. Supp. 271 (1st Dep't, 1903).

Bobbs-Merrill Co. v. Straus, 139 Fed. 155, 160 (C.C. N.Y., 1905).

${ }^{50}$ Ibid., at 159, 174. 
visions included in these broader schemes may be viewed as a means of extending to dealers a quid pro quo for an agreement not to deal in the products of competing manufacturers. This use of resale price maintenance (as part of a larger agreement designed to monopolize trade) is exemplified by early antitrust cases involving wallpaper, ${ }^{60}$ enameled iron ware, ${ }^{61}$ whiskey, ${ }^{62}$ and watch cases. ${ }^{63}$ When the number of producers is small, the same results have been achieved without formal agreement through price leadership. Fashion patterns ${ }^{64}$ and

${ }^{\circ}$ Continental Wallpaper Co. v. Voight \& Sons Co., 212 U.S. 227 (1909) (see exhibits 1 and 2 reproduced therein), involved a combination of more than thirty formerly competing concerns, which manufactured and sold upwards of 98 per cent of all the wallpaper sold in the United States. These formerly competing firms, while maintaining their separate plants and identities, placed themselves under the control of a committee which would decide the amount of production (based on capacity), patterns to be produced, prices to be charged, equalization of freight, and classification of dealers. In addition, resale prices by jobbers were jointly fixed by contract. Margins were guaranteed to jobbers, but they were obliged to purchase solely from members of the combination.

" In Standard Sanitary Mfg. Co. v. United States, 226 U.S. 20 (1912), manufacturers of 85 per cent of the country's enameled ironware joined together for the purpose of controlling the output and the price of these articles. The combination was organized by means of a patent licensing arrangement whereby Standard Sanitary's competitors became licensees under Standard Sanitary's patents. The agreement covered selling schedules, royalties, and the selling price to jobbers (to be determined by a committee of manufacturers), and included penalty provisions for price violations. Ibid., at 43 . There was a provision for return of 80 per cent of the royalty if provisions of the agreement were adhered to. The agreement with the jobbers and dealers provided that they could not deal in the products of others not licensed under the agreement, and that resale prices as established from time to time were to be strictly maintained by jobbers and dealers. Sales could not be made from one jobber to another for any better prices than "established by the sheets." Ibid., at 46. Sales were not made to jobbers and dealers who did not join the arrangement. Resale price maintenance was an inducement to jobbers and dealers to execute the agreements. Wayman, who directed the manufacturers at the time, wrote to jobbers pointing out that this was "a matter entirely for the jobbers' benefit" and "[would] be much more advantageous than a continuous cut market." Ibid., at 47.

${ }^{62}$ An early combination of distillers used resale price maintenance to secure exclusivedealing contracts with distributors. In U.S. v. Greenhut, 51 Fed. 205 (N.D. Ohio, 1892), the defendant had acquired some 70 distilleries and controlled over three quarters of the distillery output in the United States. Distillers' distributors were given rebates if they sold at not less than the price fixed and if they bought only goods produced by the defendants.

os A similar arrangement was attempted in the sale of watch cases. In Deuber WatchCase Mfg. Co. v. Howard Watch \& Clock Co., 66 Fed. 637 (C.A. 2d, 1895), the complaint alleged that beginning in 1887 , some 20 defendants mutually agreed to refuse to sell their goods to anyone who did not purchase exclusively from them and to maintain a fixed price on all goods manufactured by them.

* Pattern-makers used resale price-maintenance agreements in conjunction with agreements not to deal in the products of competitors for many years prior to the Supreme Court decision in Standard Fashion Co. v. Magrane-Houston, 258 U.S. 346 (1922). At that time two firms, Butterick and McCall's, probably did 80 per cent of the fashion business done through retail stores in the United States. See Standard Fashion Co. v. MagraneHouston, 259 Fed. 793, 798, 803 (C.A. 1st, 1919).

A large amount of litigation regarding dealer contracts involving the pattern sales of a 
sparkplugs ${ }^{65}$ are examples; both of these industries contain very few firms.

In the foregoing examples manufacturers were organized or were few in number and dealer co-operation was sought in the form of agreements or understandings not to deal with competing manufacturers. Manufacturers in turn guaranteed resale margins by means of resale price maintenance. The plans for exclusive distribution appear to have been sponsored by the manufacturers, but resale price maintenance was generally recognized also to be in the interest of the dealers.

These examples suggest an attempt to enlarge the advantage of both dealers and manufacturers by "trading" or "bargaining." The inclusion in the agreements of clauses preventing the dealers from buying the products of concerns competing with the organized manufacturers was an attempt by manufacturers to lessen the advantages of competitors or to protect themselves from the growth of outsiders. Not dealing with outsiders was costly to the organized dealers. It had to be paid for. The price was resale price maintenance for the dealers.

Two assumptions are implicit in this explanation of resale price maintenance. First, the advantage gained for dealers by the elimination of price competition among them must outweigh the loss which they suffer by being prohibited from dealing with certain suppliers or poten-

number of companies over an extended period reveals that the contracts almost uniformly provided for twice-yearly return of old patterns for full or $9 / 10$ ths credit on new patterns, an agreement not to deal in the patterns of competitors, sales and display on a ground floor location near the front door, and resale price maintenance of the pattern prices. See Weiboldt v. Standard Fashion Co., 80 III. App. 67 (1898); Butterick Publishing Co. v, Rose, 141 Wis. 533, 124 N.W. 647 (1910) ; Peerless Pattern Co. v. Gauntlett Dry Goods Co., 171 Mich. 158, 136 N.W. 1113 (1912); Sullivan v. Rime, 35 S.D. 75, 150 N.W. 556 (1915); Pictorial Review Co. v. Pate Bros., 185 S.W. 309 (Tex. Civ. App., 1916). The McCall Company modified its dealer contracts after the decision of the Supreme Court in Dr. Miles Medical Co. v. Park \& Sons Co., 220 U.S. 373 (1911), but in actual effect the practice remained the same. McCall's dealers could take competing lines and sell at any price, but if they did, McCall would not take back unsold patterns for credit. This in effect required both resale price maintenance and exclusive dealing if McCall's patterns were to be handled. See Hearings on Trust Legislation before the House Committee on the Judiciary, 63d Cong. 2d Sess. 1006 (1914).

${ }^{65}$ In the sale of spark plugs, a field dominated by three firms, Champion, A-C (General Motors), and Electric-Autolite, all of which price-maintain, a large proportion of sales are made through gasoline service stations or through the service departments of automobile dealers. General Motors and its dealers use and sell A-C plugs exclusively; Chrysler cars come equipped with the Autolite product and dealers handle this brand; while Ford and most other makers equip with and sell Champion plugs exclusively. A similar situation exists with service stations. Standard Oil Co. service stations, for example, which carry and sell their own brand of Atlas tires, batteries, and other accessories, sell AtlasChampion spark plugs exclusively. They are assured that the same or similar Champion plugs may not be purchased at auto supply stores or mail-order houses at lower prices. 
tial suppliers. Second, for manufacturers the opposite must be true. That is, the advantage to manufacturers of exclusive dealer outlets must outweigh the disadvantage of having no price competition in distribution. These conditions seem most likely to be met when there are relatively few manufacturers and relatively large-scale operation is required for efficient production; for then, foreclosing all but a small proportion of the dealer outlets makes it more difficult for outside manufacturers to reach efficient size. If, however, it takes relatively few dealers to support an efficient manufacturer, both the dealer organization (which depends on co-operation from manufacturers for successful operation) and the manufacturer organization are more likely to be undermined.

Other factors are also pertinent to the evaluation of the possible success of agreements between dealers and manufacturers. If the market demand for the product (as contrasted to the demand for the product of each manufacturer) is relatively insensitive to price changes, guaranteeing resellers' margins is less costly to manufacturers and more advantageous to dealers. Also, if the co-operating manufacturers make trade-marked or branded products which have high consumer acceptance, which is maintained in part by the organized dealers, the entry of competing manufacturers will be more difficult.

If these vertical agreements are to benefit the manufacturers in the way described (adverse effect on outsiders or new entrants), the case would seem to be analytically indistinguishable from the proposition that vertical integration prolongs monopoly by imposing greater capital requirements on prospective entrants. This view, although widely held, has been seriously questioned. ${ }^{66}$

Foreclosing dealer outlets to prospective manufacturers means in effect that new competition requires entrance on both levels at once. If, however, there are greater than competitive profits, the question is raised as to why the increased capital necessary is not forthcoming. ${ }^{67}$ But apart from capital requirements it is possible that risks of successful entry are increased by vertical agreement. When the range and diversity of product sales required for successful operation on one level (reselling) is much broader than the other (manufacturing), it is possible that combining the proper proportions for successful operation on each level is a complicated, risky, time-consuming process. Securing

${ }^{\infty}$ Consult Bork, Vertical Integration and the Sherman Act, 22 U. of Chi. L. Rev. 157, 195 (1954).

" Ibid. 
dealer customers is not costless, as the makers of the Kaiser automobile knew or learned.

The possible usefulness of resale price maintenance when both sellers and resellers are organized is suggested by bilateral monopoly analysis. ${ }^{68}$ Here the interests of the seller and the buyer (reseller) are presumed to be in conflict. In the absence of agreement, output and price are indeterminate, and an output (or prices) which will maximize joint return will not be reached. This is to say that vertical agreement makes possible the division of a larger pie irrespective of how it is sliced. For this reason it is often said that bilateral monopoly leads to merger. Fixing a resale price (the dealer margin determining the division of shares) is a conceivable substitute for merger in achieving joint maximization. For this purpose it is necessary that a particular price be set. Setting a minimum price is insufficient unless for practical purposes the minimum price will become the going price. ${ }^{69}$

\section{Summary and Evaluation of Conditions Favorable to Resale Price Madntenance}

The interest of dealers in resale price maintenance is that of reducing price competition. To be successful for this purpose it is necessary that competing products and competing dealers be kept under control. If competing products can also be put under resale price maintenance or product differentiation encouraged, the effect of competition from those products will be minimized. A rigorous enforcement of the maintained prices under the "fair-trade" laws is necessary to prevent competition from dealers who do not maintain price. Insofar as resale price maintenance is successful in eliminating price competition among dealers, competition in non-price areas, such as service and convenience, is increased, and the entry of new dealers is made more attractive. Low-cost, non-service dealers whose merchandising policies involve high turnover and low mark-ups are prevented from selling pricemaintained merchandise at low margins.

Most manufacturers do not find resale price maintenance in their interest because it is inconsistent with selling the most merchandise at the lowest possible cost. Dealer competition forces the development of

\footnotetext{
${ }^{68}$ Consult, for example, Stigler, The Theory of Price 241 (1952); or Fellner, Competition among the Few 244 (1949).

${ }^{\infty}$ In the extreme case-a single buyer and a single seller-setting a minimum resale price would leave the reseller free to raise his sale price to the detriment of the original seller. This would make for the sale of a smaller quantity of product and consequent lower prices than is consistent with joint maximization.
} 
efficient merchandising methods, making for lower retail prices and greater sales without reducing per-unit return to manufacturers. Manufacturers support resale price maintenance, however, under conditions which in economic terms may involve (a) dealer monopoly and competing manufacturers, (b) bilateral monopoly (monopoly by dealers and by manufacturers), and (c) monopoly in manufacturing and competition among dealers. Each of these requires special conditions before price maintenance can be effective. Price maintenance appears to be incompatible with an assumption of pure competition among both sellers and resellers. In economic terms it is the "monopoly" aspect of markets rather than the "competitive" aspect which is most relevant to an understanding of the motivations for resale price maintenance. This is so whether a particular use of resale price maintenance has come about through coercion by dealers, as a result of bargaining between organized dealers and organized manufacturers, or as a means of assuring performance of essential dealer services.

Both the methods and the objectives of resale price maintenance are limited by the application of antitrust law to horizontal agreements. For this reason, many present uses of resale price maintenance are unquestionably subject to legal attack. Not all departures from conditions of "free and open competition," however, involve violation of the antitrust laws under current standards. Insofar as resale price maintenance achieves its objectives, whether or not it falls within the scope of the antitrust laws, it has an anti-competitive effect on the economy.

To state that the practice of maintaining prices for resale involves a departure from the conditions posited by competitive analysis is not to solve the question of whether the practice should be prohibited or permitted, even for those who are willing to assume that competition is an evaluative as well as descriptive device. Insofar, however, as resale price maintenance can be shown to make for more or for less competition than would prevail were it prohibited, then at least one guidepost to public policy may be clarified.

\section{Effect of Resale Price Maintenance on Prices}

Proponents of fair-trade laws argue that resale price maintenance does not eliminate competition or raise prices. The analysis to this point concludes that resale price maintenance is inconsistent with competition. Another, and possibly more convincing evaluation, involves empirical evidence as to the actual effect of resale price maintenance in terms of the prices charged. 


\section{A. Prior Studies}

If, as has been suggested, resale price maintenance can be expected to make for less rather than more competition, it is reasonable to expect that its use would make for higher consumer prices. A number of price studies have been undertaken in an effort to show the price effects of resale price maintenance. Some show higher prices, some lower. The general conclusion has been that more evidence is needed.

One type of price study involves the measurement of magnitudes of price increases over periods of time. This kind of study indicates that in those periods in which prices are generally rising, prices increased less on fair-traded products than on non-fair-traded products. ${ }^{70}$ The evidence indicates, for example, that the consumer price index (exclusive of rent) rose 96 per cent from the middle 1930's (1935-1939 average) to 1951 . In contrast the price increases on selected "fairtrade" items were: ${ }^{71}$

\begin{tabular}{|c|c|c|}
\hline & $\begin{array}{c}1935-1939 \\
\text { Index }\end{array}$ & $\begin{array}{l}1951 \\
\text { Index }\end{array}$ \\
\hline Two-slice Toastmaster. & $100(1936)$ & 143.0 \\
\hline Aspirin Tablets. . . . . . . . . . . & 100 & 100.3 \\
\hline Toothpaste............... & 100 & 140.8 (March) \\
\hline Razor Blades.............. & 100 & 106.4 (March) \\
\hline All Prescriptions and Drugs..... & 100 & 128.0 \\
\hline Sanitary Napkins. . . . . . . . . . . & 100 & 200.3 (March) \\
\hline
\end{tabular}

This kind of evidence, of course, does not indicate that fair-trade prices are lower than non-fair-trade prices. It purports to show that prices increase less on typically fair-traded items than on consumption goods generally. But there is wide variation in the degree of price change among both fair-traded and non-fair-traded items, and this suggests an alternative explanation. In general, it can be shown that the items which increase the least during a period of rising prices are the items which fall the least during a period of falling prices. ${ }^{72}$ There is no evidence to indicate that the most rigid prices are the most competitive prices.

If, for example, the cost of producing and distributing food rose as much as the price of food (127 per cent), and the cost of producing and distributing aspirin did not rise as the price of aspirin did not rise, the price comparisons are readily explained by cost changes without

${ }^{70} \mathrm{Op}$. cit. supra note 42 , at 19. ${ }^{71}$ Ibid.

72 TNEC, Investigation of Concentration of Economic Power Monograph No. 1, Price Behavior and Business Policy, 76th Cong. 3d Sess. 170 (1940). 
reference to fair trade. But if the cost of making and selling aspirin rose more than the price, a departure from competitive conditions in the sale of aspirin in the early period might be indicated; or, as Grether has pointed out, resale price maintenance is not feasible when flexibility characterizes retail price. ${ }^{73} \mathrm{He}$ suggests the gap between manufacturer's price and price to consumers is necessarily wide to achieve the stability to make price maintenance workable. ${ }^{74}$ These price index results are not conclusive for the purpose of judging the effects of fair trade.

A second type of price study compares the legal minimum prices for certain fair-trade products with the prices at which particular stores in non-fair-trade areas sell these items. For example, a comparison involving 208 typically fair-traded products sold by drug stores indicated that retail margins and consumer prices were greater in fair-trade than in non-fair-trade states. ${ }^{75}$ Similar best-buy studies have been made for other fair-trade commodities in particular population centers with similar results. For example, the St. Louis Star-Times in 1951 compared liquor prices in St. Louis, Missouri, with prices across the river in Illinois, finding the latter sixteen per cent higher than the former. ${ }^{78}$ Studies of the type just described have been criticized because they involve selective comparisons which distort or at least magnify the overall result in favor of resale price maintenance.

One of the most comprehensive studies of the effects of fair trade, the Druggist Research Bureau study of 1941, indicates that fair trade does not increase prices. The study surveyed prices on fifty fast-moving fairtraded items sold in drug stores, reporting prices before fair trade (from memory) and currently (1939). Reports from independent stores were made on the prices at which the majority of sales were made, and chain stores reported an average of everyday and an average of special prices. Prices in the fair-trade states were found to have decreased slightly. Prices were found to have increased after fair trading was begun in the

Grether, Price Control under Fair Trade Legislation 283 (1939).

${ }^{76}$ Tbid.

"Hearings on Resale Price Maintenance before the Antitrust Subcommittee of the House Committee on the Judiciary, 82d Cong. 2d Sess. 433 (1952). (Study referred to was made by or for Mr. Rosenthal, owner of Standard Cut Rates store in Washington, D.C.)

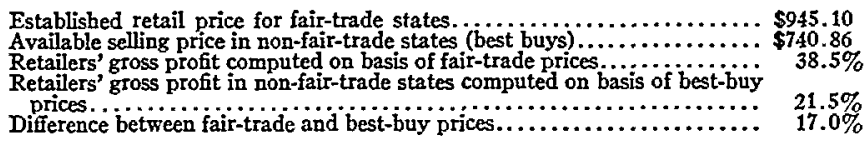

"Ibid., at 839. 
largest cities (three per cent), in chain stores (six per cent), and in large independent stores in large cities (slightly). Prices were found to have decreased in small stores and in small towns.

For several reasons there may be considerable doubt whether average prices actually decreased, and whether, if they did, the decrease was due to resale price maintenance. First, independent stores reported only those prices at which most sales were made. It is at least possible that a store making forty-nine per cent of its sales at cut prices before fair trade and none of its sales at cut prices after fair trade would show a "no-price-change" result. Second, the decreases (in the classes where decreases occurred) were as great in non-fair-trade states as in fair-trade states. It is not shown whether dealer margins were made more favorable for small independents as against large chain buyers by passage of the Robinson-Patman Act in 1936 (and note the critical importance of this date to the study under review). Independent study of selected drug items does indicate that small buyers got better prices after $1936 .^{77}$ Small stores may have passed these savings on to consumers. This would make for price declines for independents (in contrast to chain stores) irrespective of fair trade and is consistent with the findings of the Druggist Research Bureau study indicating that prices for small stores decreased in both fair-trade and non-fair-trade states. ${ }^{78}$

\section{B. Nature of the Dentifrice Study}

The data for the study of toothpaste prices were obtained from the Market Research Corporation of America. This organization, to provide market data on consumer purchases to private clients, maintains a national consumer panel of about 4,500 families, each of which keeps a daily record of household purchases classified by product type, brand, size, and price. Three states containing panel families, Texas, Missouri, Vermont, in addition to the District of Columbia, have not had fairtrade laws. This permits comparison of prices in non-fair-trade states with those paid for the same goods in comparable fair-trade areas.

\footnotetext{
"7 Op. cit. supra note 72 , at 393.

${ }^{78} \mathrm{~A}$ more recent study of the effects of fair trade on the prices of heavy-volume, fastmoving drug items, was made by the A. C. Nielsen Co., covering the period March through August, 1951. On the basis of bimonthly store audits of 70 sample stores in three nonfair-trade states and the District of Columbia, as compared with sales in 700 sample stores in the rest of the country, the weighted composite price (weighted in terms of dollar volume) on 24 drug store items showed prices on the average to be slightly higher in the non-fair-trade states than in the fair-trade states. A similar study had been made by this company in 1949 with similar results.
} 
Panel families in the four non-fair-trade areas and in comparable fairtrade areas were as follows:

Non-Fair Trade

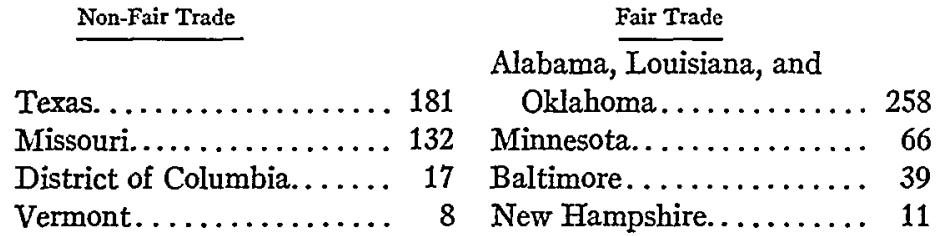

Because of the limited number of panel families available there, and because of the danger of introducing locational effects by combination with western states, the District of Columbia, Vermont, Baltimore, and New Hampshire were excluded. States finally included were Alabama, Louisiana, Oklahoma, Minnesota, Missouri, and Texas. The fairtrade states were selected on the basis of total population, proportion of urban and rural population, ${ }^{79}$ and geographical proximity. The 313 panel families from Texas and Missouri appeared quite comparable to the 324 panel families from Alabama, Louisiana, Oklahoma, and Minnesota. ${ }^{80}$

Toothpaste is purchased by consumers fairly frequently and in small quantities. The outlay at any one time is usually less than one dollar. ${ }^{81}$ Dentrifices are sold in various forms-pastes, powders, and liquids. Some are ammoniated, and some contain chlorophyll or other special

7

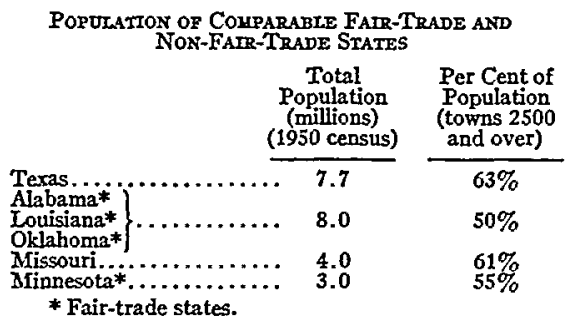

The national consumer panel was not designed for accurate representation of individual states or minor geographical subdivisions. The sample (originally a quota sample, later gradually transferred into a probability sample) was designed to represent only broad geographic areas. One result of this is that the number of rural as contrasted to urban families is greater in the areas compared than in the national totals. Consequently, weights have been assigned to the different size places to approximate national proportions.

${ }^{\infty}$ The groups compared were similar in terms of family composition, income, and education. See Appendix Table 7 .

${ }^{21}$ In these respects the dentifrice study covers a product fairly typical of the items included in the Druggist Research Bureau study. In addition, an attempt has been made to isolate the possible effects of price maintenance by controlling for geographic area, community size, type of outlet and comparable time periods without depending upon memory with respect to long-past purchases. 
ingredients. They are also sold in a wide range of sizes. About seventyfive per cent of all dentifrice purchases are of so-called regular toothpaste. $^{82}$ Dentifrices with special ingredients, or in liquid or powder form, together account for the remaining twenty-five per cent. The study was confined to regular toothpastes price-maintained in fair-trade states at 63,47 , or 27 cents. ${ }^{83}$ Within each of the three size categories of 63,47 , and 27 cents, the major price-maintained brands were combined. ${ }^{84}$ Brands included account for more than ninety per cent of regular toothpaste sales and more than two-thirds of all dentifrice sales.

Toothpaste sales are made in food stores, drug stores, dime stores, and by mail-order houses and door-to-door salesmen. The most important outlets are food and drug stores. All other outlets have been combined in this study to form a third category.

The data in the study are also analyzed in terms of community size. Purchases by families living in cities of 10,000 population and over are compared to purchases by families living in places of less than 10,000 inhabitants.

Data analyzed include purchases made between January 1, 1951, and January 31,1953 . During this period the legal status of resale price maintenance was changed twice: first, by the decision of the United States Supreme Court in Schwegmann Bros. v. Calvert Corp. ${ }^{85}$ in May, 1951, and second, by passage of the Federal Fair Trade Act (McGuire Act) ${ }^{86}$ in July, 1952. The Schregmann case made resale price maintenance unenforceable against dealers who had not signed pricemaintenance contracts. Prior to this decision the great majority of dealers had not signed such contracts; they were thought to be bound by simple notice from the manufacturer. The McGuire Act provided

${ }^{82}$ The Market Research Corporation of America survey of dentifrice purchases in the United States for January-September, 1951 indicates that 74.3 per cent of total sales were regular pastes; all others, 25.7 per cent. Sales of regular pastes by the three largest selling brands comprised 63.4 per cent of the dollar value of all dentifrice sales in this period.

83

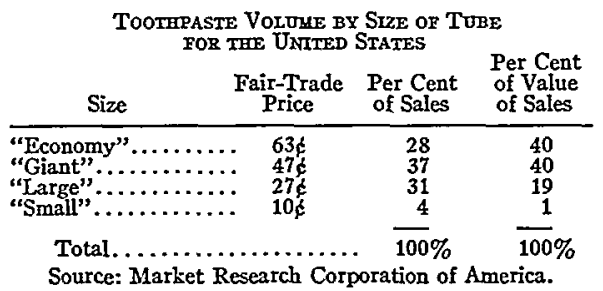

a No changes in list prices were made during the whole period under review for the toothpastes included in this study.

${ }^{8} 341$ U.S. 384 (1951).

${ }^{86} 66$ Stat. 632 (1952), 15 U.S.C.A. $\$ 45$ (Supp., 1952). 
enabling legislation binding non-signers in states having fair-trade laws. 87

The study, therefore, analyzes the toothpaste data in fair-trade and non-fair-trade states in terms of tube size, type of outlet, community size, and time period. ${ }^{88}$

\section{Conclusions}

1. Lack of Adherence to Maintained Prices. A high proportion of toothpaste sales in both fair-trade and non-fair-trade states is made at prices below the stipulated minimums-almost one half of the sales in non-fair-trade states and more than one third in fair-trade states. ${ }^{89}$ Substantial sales were also made above minimum established prices in both fair-trade and non-fair-trade states. ${ }^{90}$ These results are unchanged when the data are measured in terms of value of sales rather than number of sales. ${ }^{91}$ The high percentage of sales made below minimum

${ }^{87}$ Twenty states have upheld the constitutionality of non-signer clauses. In seven states, Arkansas, Colorado, Florida, Georgia, Michigan, Nebraska, and Utah, the application of state fair-trade laws to non-signing dealers has been held to violate the state constitution. See 1 CCH Trade Reg. Rep. 3085 (10th ed., 1954).

${ }^{8 s}$ Appendix Table 4 indicates the distribution of purchases in each tube size in each of the 18 resulting categories.

${ }^{80}$ In the non-fair-trade states, 49 per cent of all sales for the entire period covered were made at prices below the minimum maintained prices in the fair-trade states. 36 per cent of all sales were made below minimum prices in fair-trade states.

${ }^{\infty}$ In both fair-trade and non-fair-trade states, less sales were made above minimum prices than below minimum prices. The proportion of sales above minimum was higher among non-fair-trade states than for fair-trade states-for fair-trade states, 17 per cent; for non-fair-trade states, 24 per cent. The difference her, arises principally because of the high proportion of 2?-cent pastes sold in non-fair-trade states for more than 27 cents. (See Appendix Table 1C.)

${ }^{01}$ The following table indicates percentages above and below minimum prices in terms of number of sales of all tube sizes and in terms of value of all sales for fair-trade and non-fair-trade states:

\begin{tabular}{|c|c|c|}
\hline & Fair Trade & $\begin{array}{l}\text { Non-Fair } \\
\text { Trade }\end{array}$ \\
\hline $\begin{array}{l}\text { Sales below minimum price. . . ............... } \\
\text { Value of sales below minimum fair-trade value... }\end{array}$ & $\begin{array}{l}36 \% \\
30 \%\end{array}$ & $49 \%$ \\
\hline $\begin{array}{l}\text { Sales above minimum price........................ } \\
\text { Value of sales above minimum fair-trade value... }\end{array}$ & $\begin{array}{l}17 \% \\
17 \%\end{array}$ & $\begin{array}{l}24 \% \\
24 \%\end{array}$ \\
\hline
\end{tabular}

Note: City sales weighted .68; town and rural sales .32 .

Source: Appendix Tables $2 \mathrm{~A}$ and $2 \mathrm{~B}$.

The percentage of number of sales above and below minimum prices in fair-trade and non-fair-trade states for each tube size was as follows:

\begin{tabular}{|c|c|c|c|c|}
\hline \multirow{2}{*}{$\underset{\text { Price }}{\text { Arinimum }}$} & \multicolumn{2}{|c|}{$\begin{array}{c}\text { PER CENT of SAIES } \\
\text { BELOW MIN.* }\end{array}$} & \multicolumn{2}{|c|}{$\begin{array}{c}\text { Per CENT OF SATES } \\
\text { ABOVE MINN.* }\end{array}$} \\
\hline & Fair Trade & $\begin{array}{l}\text { Non-Fair } \\
\text { Trade }\end{array}$ & Fair Trade & $\begin{array}{c}\text { Non-Fair } \\
\text { Trade }\end{array}$ \\
\hline $\begin{array}{l}63 k \ldots \\
47 k \ldots \\
27 k . .\end{array}$ & $\begin{array}{l}36 \% \\
27 \% \\
40 \%\end{array}$ & $\begin{array}{l}57 \% \\
47 \% \\
39 \%\end{array}$ & $\begin{array}{l}12 \% \\
28 \% \\
11 \%\end{array}$ & $\begin{array}{l}9 \% \\
30 \% \\
32 \%\end{array}$ \\
\hline
\end{tabular}

* Weighted: cities .68, towns and rural .32. 
prices in fair-trade states emphasizes widespread lack of adherence to maintained prices in toothpaste sales.

2. Higher Prices in Fair Trade States. Fair trading makes for significantly higher toothpaste prices. ${ }^{92}$ This was true before and after the outlawing of the non-signer clause by the Schwegmann case and before and after the passage of the McGuire Act. ${ }^{93}$ The conclusion holds also in cities and in smaller communities, ${ }^{94}$ and for food stores, drug stores, and other outlets. ${ }^{95}$ This result, however, is occasioned by price differences among large paste sizes (63- and 47-cent pastes) and is not true of the 27-cent size. ${ }^{\text {96 }}$

3. Lower Prices in Cities. Toothpaste prices are lower in cities than in towns and rural areas in both fair-trade and non-fair-trade states. ${ }^{97}$ Here again this result reflects prices of the larger size pastes and is not true of the smaller size. Non-fair-trade prices are lower than fair-trade prices in both large and small communities but the difference tends to be greater in the former.

\section{Minor Differences by Type of Outlet. The role of the drug-store}

${ }^{22}$ Consumers living in non-fair-trade states paid on the average 42.2 cents for toothpastes which would have cost 44.7 cents had all sales been made at the maintained minimum prices. Prices paid by these consumers were on the average 5.6 per cent below minimum prices.

Consumers living in fair-trade states paid on the average 44.9 cents for toothpastes which would have cost 46.6 cents had all sales been made at the maintained minimum prices. Prices paid by these consumers were on the average 3.6 per cent below minimum prices.

${ }^{23}$ See note 100 infra.

st See note 97 infra.

${ }^{25}$ See note 98 infra.

${ }^{\circ 6}$ The lower average prices paid for toothpaste in non-fair-trade as contrasted to fairtrade states reflects the effect of lower prices paid for the 63-cent and 47-cent sizes in non-fair-trade states. On the 27-cent size, differences in prices between fair-trade and nonfair-trade states were negligible, but the average price paid for 27-cent pastes was slightly higher in non-fair-trade than in fair-trade states.

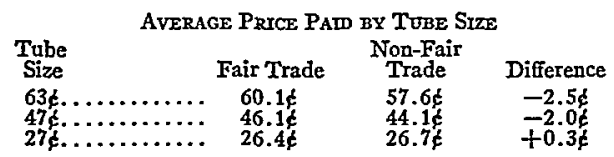

The average price paid for the 63-cent size was 4.2 per cent lower in non-fair-trade states than in fair-trade states; for the 47-cent size, 4.3 per cent lower; and for the 27-cent size, 1.1 per cent higher. See Appendix Tables 1A, 1B, and 1C. The actual distribution of price paid for each tube size in fair-trade as compared to non-fair-trade states is shown in Appendix Tables $3 \mathrm{~A}, 3 \mathrm{~B}$, and $3 \mathrm{C}$.

${ }^{\prime \prime}$ In fair-trade states purchasers living in cities paid 46.9 cents on the average for pastes the price of which would have been 49.1 cents had all purchases been made at the minimum maintained price. Fair-trade purchasers living in smaller places paid nearly the same average price they would have paid if all sales had been made at the minimum maintained prices, the difference being one-half cent or 0.5 per cent below average price minimum.

The effect of community size on toothpaste purchases in non-fair-trade states is similar to that in fair-trade states. Purchasers living in non-fair-trade cities paid 3.6 cents (7.7 
trade in sponsoring fair-trade legislation might create a presumption that drug stores cannot or do not cut prices as frequently or as much as other outlets. The study, however, does not indicate that toothpaste prices are more strictly maintained in drug stores than in food stores or other outlets either in fair-trade or non-fair-trade states. Average price differences among outlet types are not great, but there is reason to believe that among the three comparisons made-food stores with drug stores, drug stores with other stores, and food stores with other storesthat food-store prices are on the average higher, not lower, than drugstore prices. ${ }^{.8}$

5. Effect of Schwegmann Case and McGuire Act. It might be expected that prices in the fair-trade states would be lowered as a result of the Schwegmann decision, holding that non-signers were not obliged to maintain prices. The McGuire Act, which reinstituted the non-signer clause, might be expected to have the opposite effect. The Schwegmann case did have the effect of lowering toothpaste prices in fair-trade states; $^{\circ 9}$ this result was not counteracted during the six-month period

per cent) less than they would have paid if all purchases had been at the minimum maintained prices. The difference in smaller places was 1.4 cents ( 3.4 per cent).

The following table indicates the frequency of purchases among toothpaste sizes in fairtrade and non-fair-trade states in terms of community size:

\begin{tabular}{|c|c|c|c|c|c|c|c|c|c|}
\hline \multirow[b]{3}{*}{$\begin{array}{l}\text { Tube } \\
\text { Size }\end{array}$} & \multirow[b]{3}{*}{$\underset{\text { Size }}{\text { Community }}$} & \multicolumn{4}{|c|}{ FajR-Trade States } & \multicolumn{4}{|c|}{ Non-Faur-Trade States } \\
\hline & & & Aver. & Per Cen & of Sales & & Aver. & Per Cent & of Sales \\
\hline & & $\begin{array}{c}\text { No. of } \\
\text { Purchases }\end{array}$ & $\begin{array}{l}\text { Aver. } \\
\text { Price } \\
\text { Paid }\end{array}$ & $\begin{array}{l}\text { Below } \\
\text { Mlin. }\end{array}$ & $\begin{array}{l}\text { Above } \\
\text { Min. }\end{array}$ & $\begin{array}{l}\text { No. of } \\
\text { Purchases }\end{array}$ & $\begin{array}{l}\text { Aver. } \\
\text { Prid }\end{array}$ & $\begin{array}{l}\text { Below } \\
\text { Min. }\end{array}$ & $\begin{array}{l}\text { Above } \\
\text { Min. }\end{array}$ \\
\hline $\begin{array}{l}63 k . . \\
47 k . . \\
27 k . .\end{array}$ & $\begin{array}{l}\text { Cities } \\
\text { Towns and Rural } \\
\text { Cities } \\
\text { Topns and Rural } \\
\text { Cities } \\
\text { Towns and Rural }\end{array}$ & $\begin{array}{l}437 \\
233 \\
345 \\
385 \\
241 \\
492\end{array}$ & $\begin{array}{l}59.3 k \\
61.6 \\
45.4 k \\
47.4 \\
26.5 k \\
26.2\end{array}$ & $\begin{array}{l}42 \\
24 \\
31 \\
19 \\
32 \\
57\end{array}$ & $\begin{array}{l}10 \\
15 \\
17 \\
50 \\
11 \\
12\end{array}$ & $\begin{array}{l}303 \\
185 \\
445 \\
429 \\
251 \\
436\end{array}$ & $\begin{array}{l}56.6 \xi \\
59.6 \\
43.3 \xi \\
45.6 \\
27.0 \xi \\
26.2\end{array}$ & $\begin{array}{l}59 \\
52 \\
51 \\
40 \\
32 \\
53\end{array}$ & $\begin{array}{r}6 \\
16 \\
22 \\
45 \\
35 \\
25\end{array}$ \\
\hline
\end{tabular}

The lower average toothpaste prices in larger as contrasted to smaller communities results from the fact that a larger proportion of sales was made at higher than minimum prices in small places, and from the fact that proportionately more of the larger size pastes, more often sold at below-minimum prices, were sold in cities.

os

\begin{tabular}{|c|c|c|c|c|c|c|c|}
\hline \multirow[b]{3}{*}{$\begin{array}{l}\text { Tube } \\
\text { Size }\end{array}$} & \multicolumn{7}{|c|}{$\begin{array}{l}\text { Average Prices Pam for ToothPaste by TYPE of OUTIET } \\
\text { (All Communities,* All Periods) }\end{array}$} \\
\hline & & \multicolumn{3}{|c|}{$\begin{array}{c}\text { FAir-Trade States } \\
\text { Per Cent } \\
\text { of Sales }\end{array}$} & \multicolumn{3}{|c|}{$\begin{array}{c}\text { Non-FarR-Trade States } \\
\text { Per Cent } \\
\text { of Sales }\end{array}$} \\
\hline & Outlet & $\begin{array}{l}\text { Aver. } \\
\text { Price }\end{array}$ & $\begin{array}{l}\text { Below } \\
\text { Min. }\end{array}$ & $\begin{array}{c}\text { Above } \\
\text { Mlin. }\end{array}$ & $\begin{array}{l}\text { Aver. } \\
\text { Price }\end{array}$ & $\begin{array}{l}\text { Below } \\
\text { Min. }\end{array}$ & $\begin{array}{l}\text { Above } \\
\text { Min. }\end{array}$ \\
\hline $\begin{array}{l}63 \xi . \\
47 \xi .\end{array}$ & $\begin{array}{l}\text { Food Stores } \\
\text { Drug Stores } \\
\text { Other } \\
\text { Food Stores } \\
\text { Drug Stores } \\
\text { Other } \\
\text { Food Stores } \\
\text { Drug Stores } \\
\text { Other }\end{array}$ & $\begin{array}{l}60.4 k \\
60.1 \\
59.5 \\
46.2 f \\
45.9 \\
45.4 \\
26.5 k \\
26.3 \\
26.3\end{array}$ & $\begin{array}{l}37 \\
39 \\
35 \\
25 \\
28 \\
31 \\
39 \\
42 \\
38\end{array}$ & $\begin{array}{r}19 \\
8 \\
7 \\
31 \\
28 \\
22 \\
10 \\
11 \\
15\end{array}$ & $\begin{array}{l}58.3 \% \\
58.0 \\
54.6 \\
44.5 \% \\
44.0 \\
42.9 \\
26.8 \% \\
26.7 \\
26.5\end{array}$ & $\begin{array}{l}57 \\
55 \\
61 \\
48 \\
49 \\
44 \\
37 \\
49 \\
40\end{array}$ & $\begin{array}{r}9 \\
11 \\
9 \\
32 \\
27 \\
17 \\
32 \\
25 \\
30\end{array}$ \\
\hline
\end{tabular}

${ }^{\circ}$ The fact that prices in non-fair-trade states were not lowered after the Schwegmann case corroborates this conclusion. 
following the passage of the McGuire Act. ${ }^{100}$ Prices in non-fair-trade states, however, in both period 2 and period 3, continued to be lower than in fair-trade states.

6. Significance of Price Differences. The magnitude of the difference between prices paid in fair-trade and non-fair-trade states over the entire period surveyed (January, 1951 to January, 1953) in terms of percentage above or below the fair-trade price was -4.2 per cent on 63 cent pastes, -4.3 per cent on 47 -cent pastes, and +1.1 per cent on 27 cent pastes. These percentages reflect the fact that even in fair-trade states the actual prices were on the average 3.6 per cent below the established minimums.

In summary, the significant differences in toothpaste prices are between fair-trade and non-fair-trade states, between cities and smaller places, and between prices before and after the Schwegmann case in fair-trade states. In each of these comparisons, the differences are consistent among the subcategories which they include, greatly reducing. probability of chance result..$^{101}$

100

\begin{tabular}{|c|c|c|c|c|c|c|c|}
\hline \multirow[b]{3}{*}{$\begin{array}{l}\text { Tube } \\
\text { Size }\end{array}$} & \multicolumn{7}{|c|}{$\begin{array}{c}\text { AVERAGe Prices Pam for ToOmHPaste BY"Periods } \\
\text { (All Communities,* All Outlets) }\end{array}$} \\
\hline & \multicolumn{4}{|c|}{$\begin{array}{c}\text { Farr-Trade States } \\
\text { Per Cent } \\
\text { of Sales }\end{array}$} & \multicolumn{3}{|c|}{$\begin{array}{c}\text { Non-Fatr-Trade States } \\
\text { Per Cent } \\
\text { of Sales }\end{array}$} \\
\hline & $\begin{array}{l}\text { Peri- } \\
\text { od } * *\end{array}$ & $\begin{array}{l}\text { Aver. } \\
\text { Price }\end{array}$ & $\begin{array}{l}\text { Below } \\
\text { Min. }\end{array}$ & $\begin{array}{l}\text { Above } \\
\text { Min. }\end{array}$ & $\begin{array}{l}\text { Aver. } \\
\text { Price }\end{array}$ & $\begin{array}{l}\text { Below } \\
\text { Min. }\end{array}$ & $\begin{array}{l}\text { Above } \\
\text { Min. }\end{array}$ \\
\hline $27 \boldsymbol{f} \ldots \ldots$ & $\begin{array}{l}1 \\
2 \\
3 \\
1 \\
2 \\
3 \\
1 \\
2 \\
3\end{array}$ & $\begin{array}{l}61.26 \\
59.3 \\
60.7 \\
47.3 \phi \\
46.1 \\
45.2 \\
26.36 \\
26.2 \\
27.0\end{array}$ & $\begin{array}{l}25 \\
37 \\
40 \\
11 \\
27 \\
37 \\
43 \\
43 \\
30\end{array}$ & $\begin{array}{r}4 \\
8 \\
24 \\
30 \\
29 \\
24 \\
16 \\
9 \\
13\end{array}$ & $\begin{array}{l}56.2 f \\
57.4 \\
58.8 \\
44.4 f \\
44.1 \\
43.4 \\
26.6 f \\
26.6 \\
27.3\end{array}$ & $\begin{array}{l}\mathbf{5 3} \\
\mathbf{5 7} \\
\mathbf{5 8} \\
47 \\
44 \\
\mathbf{5 5} \\
48 \\
\mathbf{3 5} \\
\mathbf{3 9}\end{array}$ & $\begin{array}{r}2 \\
7 \\
17 \\
33 \\
32 \\
22 \\
30 \\
30 \\
40\end{array}$ \\
\hline $\begin{array}{l}* \text { Weigh } \\
* * \text { Perio } \\
\text { Peric } \\
\text { Peric }\end{array}$ & $\begin{array}{l}\text { ed } .68 \\
1: \mathrm{Pr} \\
2: \mathrm{Su} \\
3: \mathrm{Su}\end{array}$ & les, .32 & is and & ral. & rior & unte & \\
\hline
\end{tabular}

${ }^{101}$ See Appendix Tables 8 through $11 B$. 


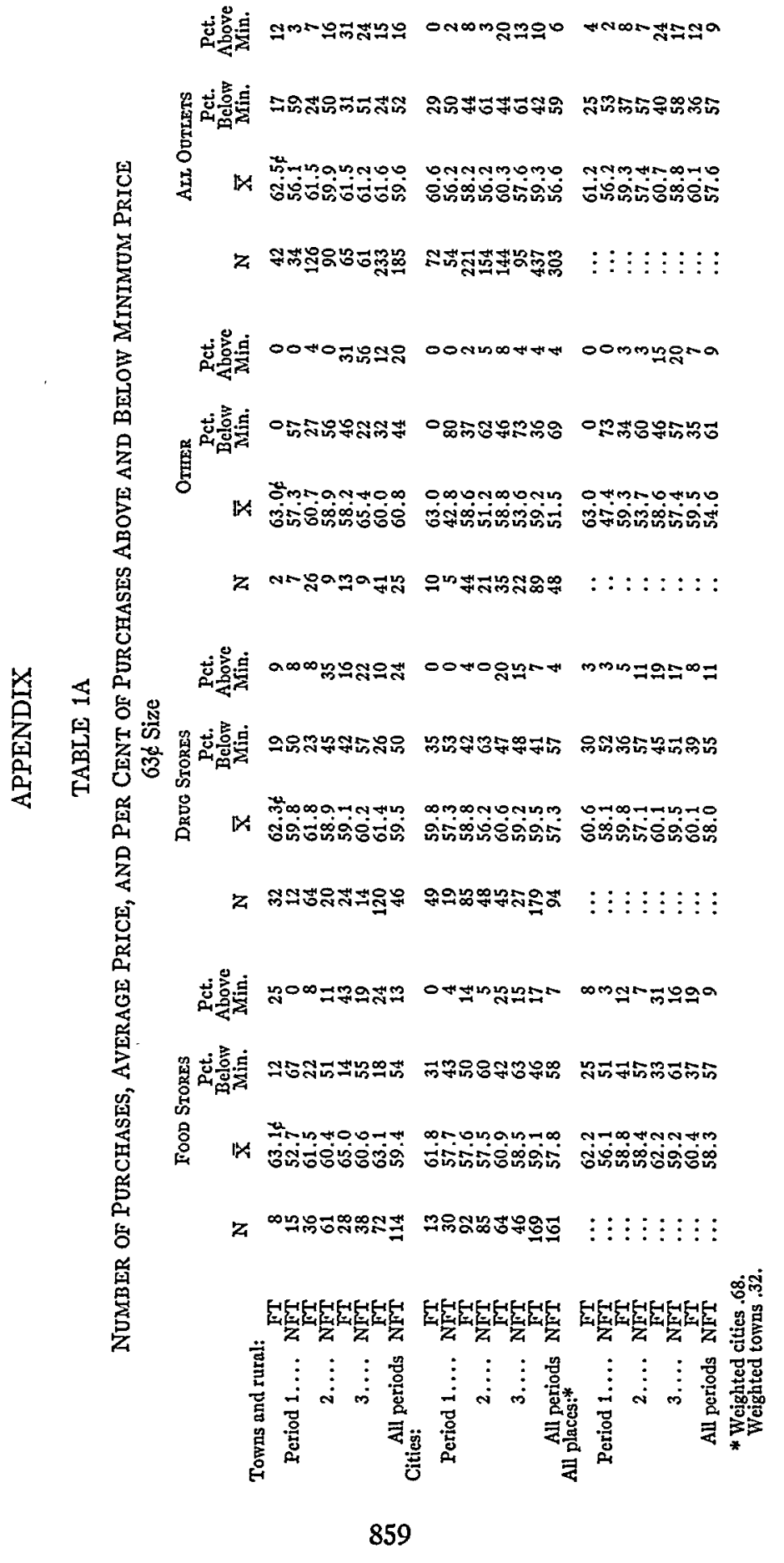




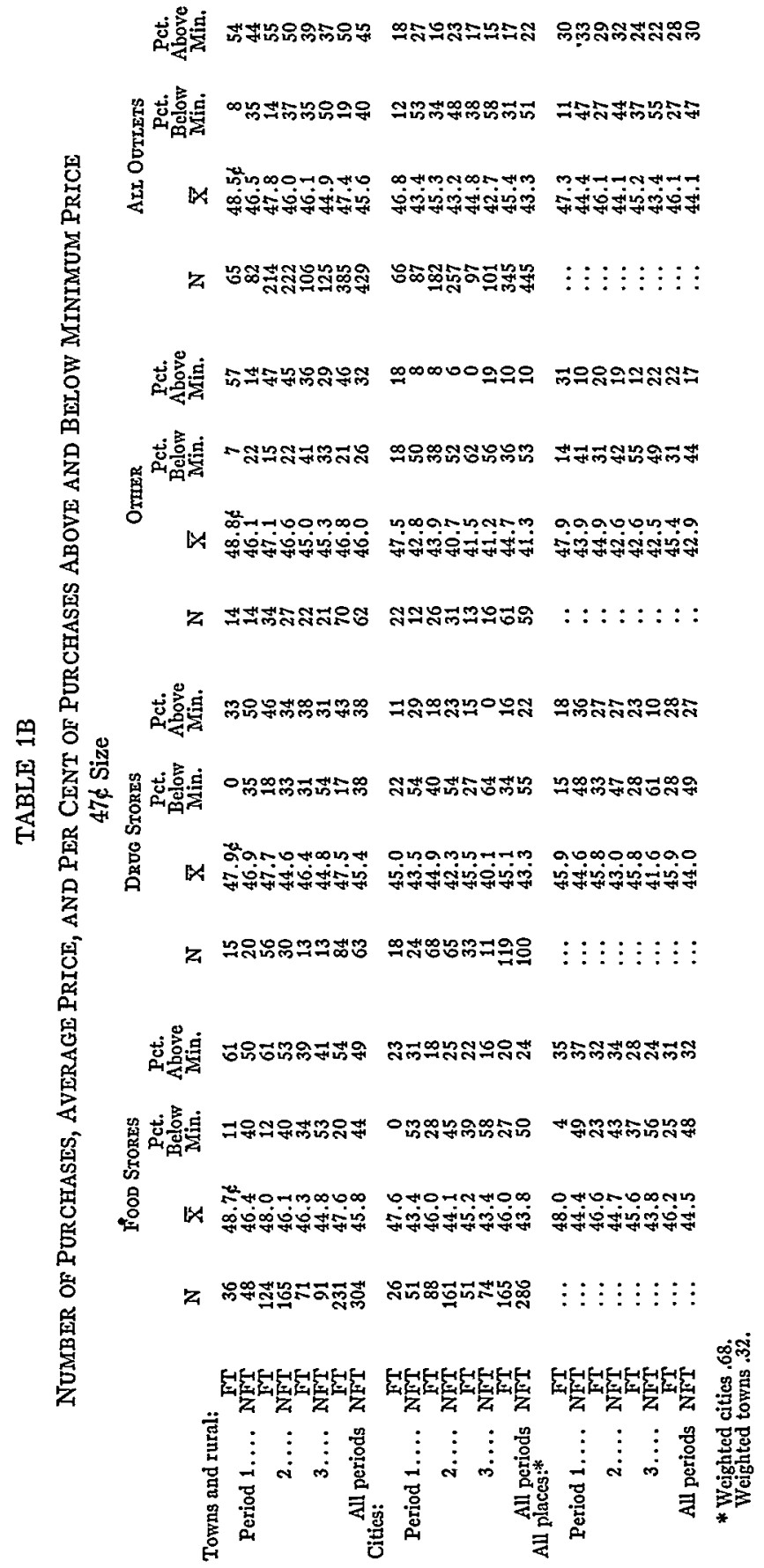

860 


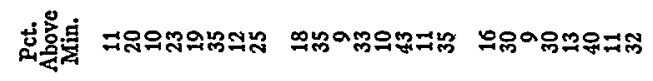

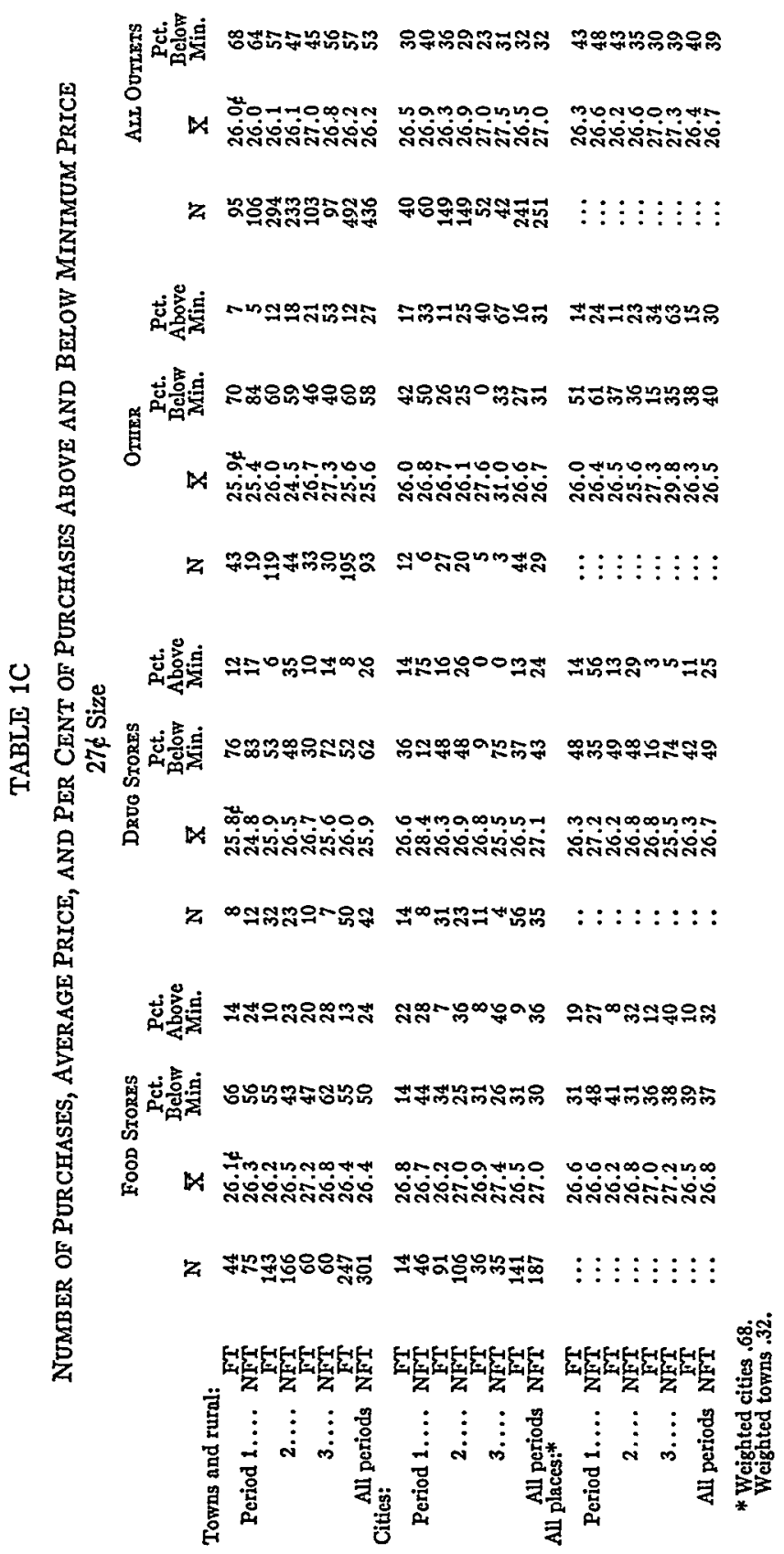

861 


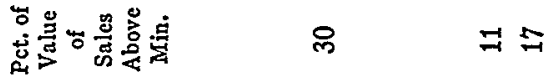

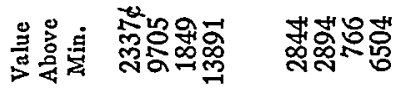

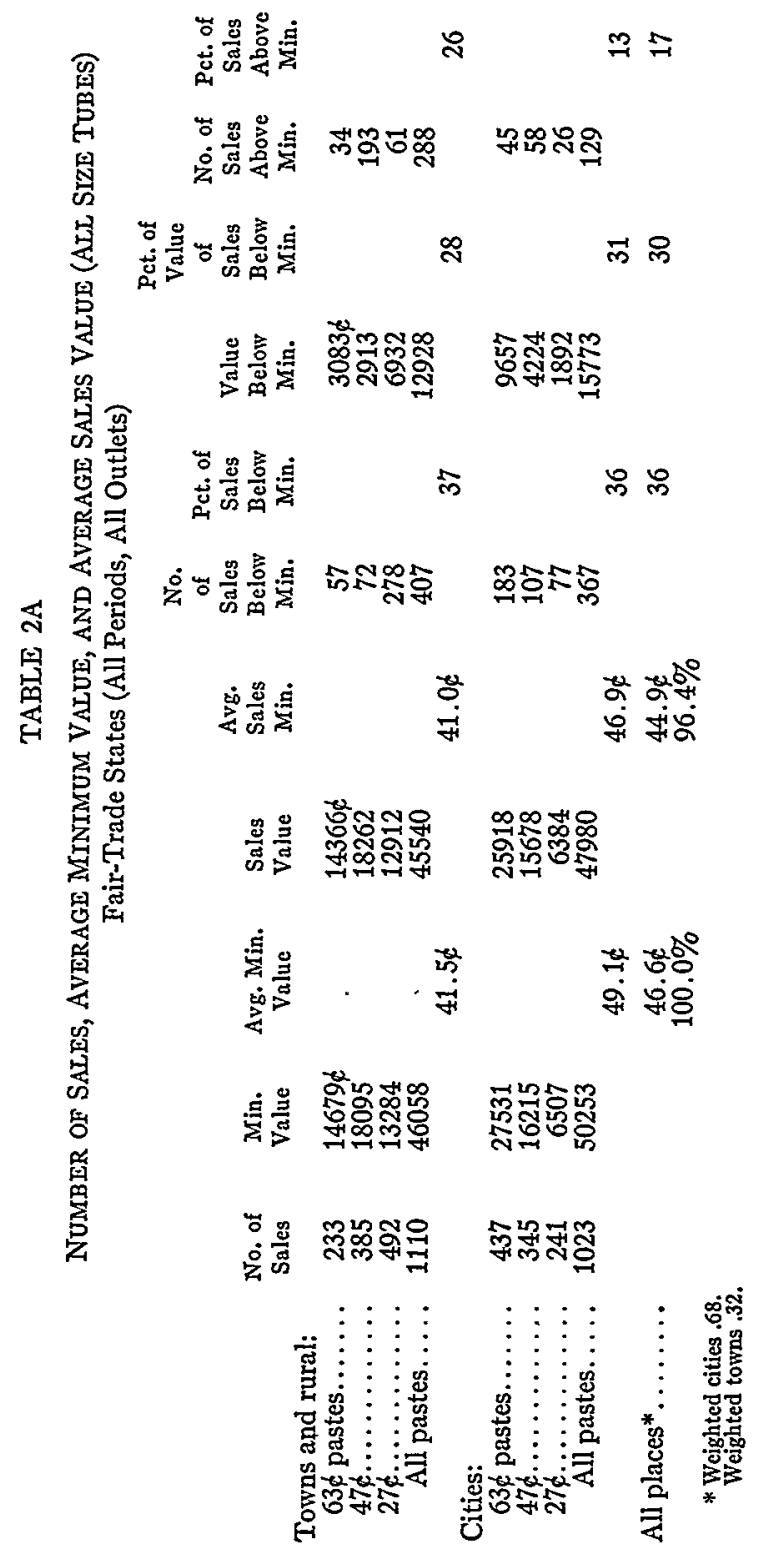




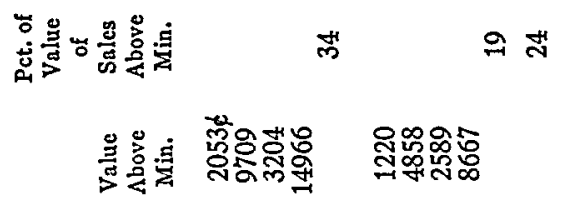

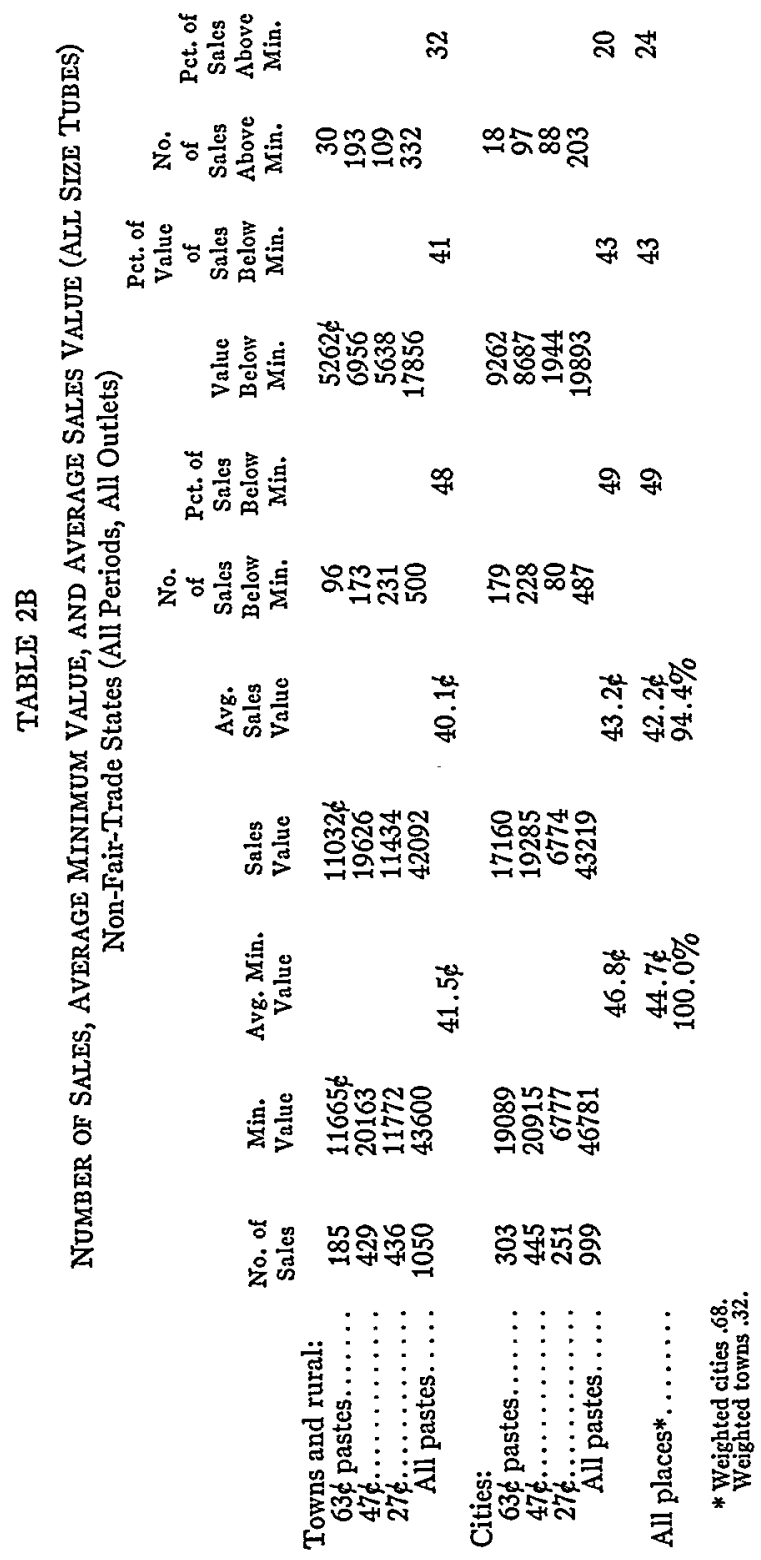


TABLE 3A

Distribution of SaAiple of TOOThPaste PURChases by PRICE IN FAIR-TRADE AND NON-FAIR-TRADE STATES (UNWEIGHTED FOR URBAN AND NON-URbaN PLACES) (ALI SIZE PLACES, AIL OUTLETS, AIL PERIODS)

63\& Size

\begin{tabular}{|c|c|c|c|c|}
\hline & \multicolumn{2}{|c|}{ Fatr Trade } & \multicolumn{2}{|c|}{ Non-Fatr Trade } \\
\hline PrICE & $\begin{array}{l}\text { Number } \\
\text { of Pur- } \\
\text { chases }\end{array}$ & Pct. & $\begin{array}{l}\text { Number } \\
\text { of Pur- } \\
\text { chases }\end{array}$ & Pct. \\
\hline \multirow{28}{*}{ 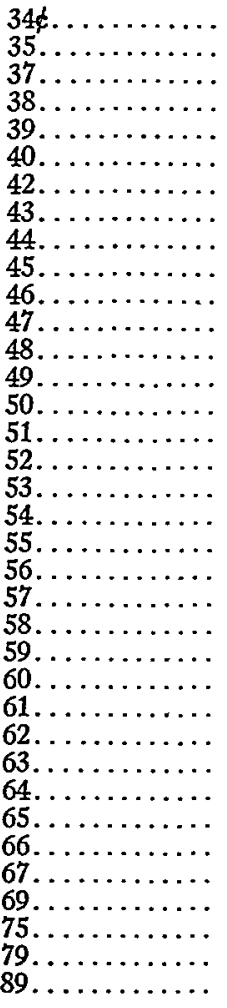 } & $\cdots$ & $\ldots \ldots$ & 3 & 0.6 \\
\hline & $\ldots$ & 舟 & 1 & 0.2 \\
\hline & 1 & 0.1 & 4 & 0.8 \\
\hline & 7 & $\cdots$ & $\begin{array}{r}7 \\
13\end{array}$ & $\begin{array}{l}1.4 \\
2.7\end{array}$ \\
\hline & & & $\begin{array}{r}0.0 \\
1\end{array}$ & 0.2 \\
\hline & 2 & 0.3 & & \\
\hline & 3 & 0.4 & 18 & 3.7 \\
\hline & 1 & 0.1 & 4 & 0.8 \\
\hline & $\begin{array}{l}4 \\
3\end{array}$ & $\begin{array}{l}0.6 \\
0.4\end{array}$ & $\begin{array}{l}8 \\
3\end{array}$ & $\begin{array}{l}1.6 \\
0.6\end{array}$ \\
\hline & 13 & 1.9 & 8 & 1.6 \\
\hline & 40 & 6.0 & 27 & 5.5 \\
\hline & 9 & 1.4 & 9 & 1.8 \\
\hline & $\begin{array}{l}11 \\
16\end{array}$ & $\begin{array}{l}1.6 \\
4.5\end{array}$ & $\cdots$ & $\cdots \cdots$ \\
\hline & 13 & 1.9 & $\because 6$ & $\cdots i .2$ \\
\hline & 3 & 0.4 & $\begin{array}{r}1 \\
18\end{array}$ & $\begin{array}{l}0.2 \\
3.7\end{array}$ \\
\hline & $\frac{1}{7}$ & $\begin{array}{l}0.1 \\
1.0\end{array}$ & $\begin{array}{r}3 \\
18\end{array}$ & $\begin{array}{l}0.6 \\
3.7\end{array}$ \\
\hline & & & 3 & 0.6 \\
\hline & $\begin{array}{r}73 \\
9\end{array}$ & 11.0 & 112 & 23.0 \\
\hline & 8 & $\begin{array}{l}1.4 \\
1.2\end{array}$ & 3 & 0.6 \\
\hline & 2 & 0.3 & 5 & 1.0 \\
\hline & 351 & 52.9 & 165 & 34.0 \\
\hline & 3 & 0.4 & 1 & 0.2 \\
\hline & $\begin{array}{l}7 \\
1 .\end{array}$ & 1.0 & 8 & 1.6 \\
\hline & 5 & 0.7 & 4 & 0.8 \\
\hline & 60 & 8.9 & 34 & 7. \\
\hline & 1 & 0.1 & 1 & 0. \\
\hline & 1 & 0.1 & $\cdots$ & ... \\
\hline & & & $\cdots$ & \\
\hline All......... & 670 & 100.0 & 488 & 100.0 \\
\hline
\end{tabular}

864 
TABLE 3B

Distribution OF SAMPLE OF TOOTHPASTE PURCHASES BY PRICE IN FaIR-Trade aNd NoN-FaIR-Trade STATES (UNWEIGHTED FOR URBAN AND NON-URBAN PLACES) (ALL SIZE PLACES, ALL OUTLETS, ALL PERIODS)

47 Size

\begin{tabular}{|c|c|c|c|c|}
\hline \multirow[b]{2}{*}{ Price } & \multicolumn{2}{|c|}{ FAmR Trade } & \multicolumn{2}{|c|}{ Non-Fatr Trade } \\
\hline & $\begin{array}{l}\text { Number } \\
\text { of Pur- } \\
\text { chases }\end{array}$ & Pct. & $\begin{array}{l}\text { Number } \\
\text { of Pur- } \\
\text { chases }\end{array}$ & Pet. \\
\hline \multirow{27}{*}{ 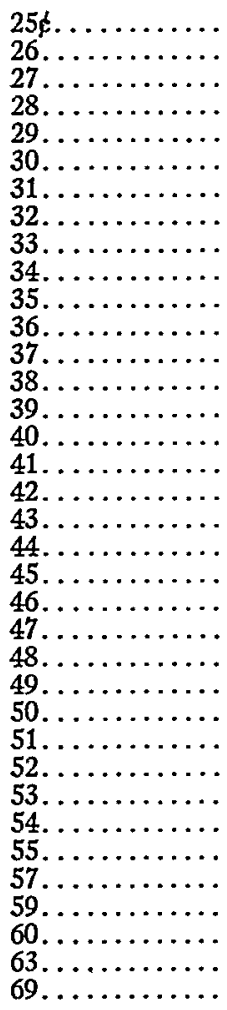 } & \multirow{9}{*}{$\begin{array}{r}\cdots \\
\cdots \\
\cdots \\
\cdots \\
2 \\
1 \\
1 \\
2 \\
3 \\
13 \\
8\end{array}$} & \multirow{2}{*}{$\cdots \cdots$} & $\begin{array}{l}8 \\
3\end{array}$ & 0.9 \\
\hline & & & $\begin{array}{l}3 \\
8\end{array}$ & $\begin{array}{l}0.3 \\
0.9\end{array}$ \\
\hline & & & 8 & 0.9 \\
\hline & & 0.3 & 30 & 3.4 \\
\hline & & 0.1 & $\frac{1}{5}$ & 0.6 \\
\hline & & 0.3 & 1 & 0.1 \\
\hline & & 0.4 & 29 & 3.3 \\
\hline & & $\begin{array}{l}1.8 \\
1.1\end{array}$ & $\begin{array}{l}3 \\
7\end{array}$ & $\begin{array}{l}0.3 \\
0.8\end{array}$ \\
\hline & & & 11 & 1.3 \\
\hline & 22 & 3.0 & 23 & 2.6 \\
\hline & 3 & 0.4 & 3 & 0.3 \\
\hline & $\begin{array}{r}19 \\
2\end{array}$ & $\begin{array}{l}2.6 \\
0.3\end{array}$ & $\begin{array}{r}36 \\
6\end{array}$ & $\begin{array}{l}4.1 \\
0.7\end{array}$ \\
\hline & 3 & 0.4 & 17 & 1.9 \\
\hline & 4 & 0.5 & 3 & $\begin{array}{r}0.3 \\
?\end{array}$ \\
\hline & 2 & $\begin{array}{l}9.9 \\
0.3\end{array}$ & $\begin{array}{r}124 \\
1\end{array}$ & $\begin{array}{r}14.2 \\
0.1\end{array}$ \\
\hline & $\begin{array}{r}13 \\
4\end{array}$ & $\begin{array}{l}1.9 \\
0.5\end{array}$ & 74 & 8.5 \\
\hline & 300 & 41.0 & 183 & 21.1 \\
\hline & 1 & 0.1 & 3 & 0.3 \\
\hline & $\begin{array}{r}75 \\
136\end{array}$ & 10.3 & $\begin{array}{r}83 \\
178\end{array}$ & $\begin{array}{r}9.5 \\
20.6\end{array}$ \\
\hline & 8 & 1.1 & & \\
\hline & 1 & 0.1 & 2 & 0.2 \\
\hline & 6 & 0.8 & 9 & 1.0 \\
\hline & $\frac{2}{7}$ & 1. & $\ddot{7}$ & 0.8 \\
\hline & 3 & 0.4 & $\cdots$ & 06 \\
\hline & $\begin{array}{l}6 \\
2\end{array}$ & $\begin{array}{l}0.8 \\
0.3\end{array}$ & $\mathbf{J}$ & 0.0 \\
\hline & 2 & 0. & 2 & 0.2 \\
\hline & 2 & & 1 & 0.1 \\
\hline All... & 730 & 100.0 & 874 & 100.0 \\
\hline
\end{tabular}




\section{TABLE $3 C$}

Distribution OF SAMPLE OF TOOTHPASTE PURChases BY PRICE IN FAIR-TRADE AND NON-FAIR-TRADE STATES (UNWEIGHTED FOR URBAN AND NON-URBAN PLACES) (ALL SIZE PLACES, ALL OUTLETS, AII PERIODS)

$27 \&$ Size

\begin{tabular}{|c|c|c|c|c|}
\hline \multirow[b]{2}{*}{ PRTCE } & \multicolumn{2}{|c|}{ FArR Trade } & \multicolumn{2}{|c|}{ Non-FaIR Trade } \\
\hline & $\begin{array}{l}\text { Number } \\
\text { of Pur- } \\
\text { chases }\end{array}$ & Pct. & $\begin{array}{l}\text { Number } \\
\text { of Pur- } \\
\text { chases }\end{array}$ & Pct. \\
\hline 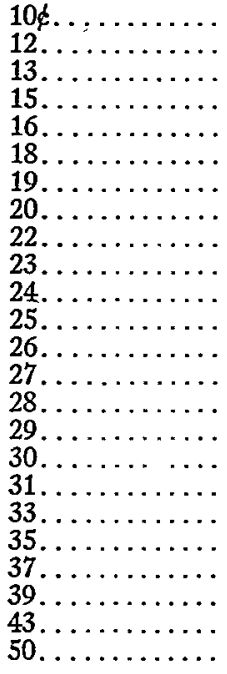 & $\begin{array}{r}\cdots \\
\cdots \\
\cdots \\
\cdots \\
1 \\
1 \\
\cdots \\
3 \\
2 \\
7 \\
1 \\
339 \\
1 \\
291 \\
11 \\
54 \\
12 \\
\cdots \\
\cdots \\
7 \\
\cdots \\
\cdots \\
2 \\
1\end{array}$ & $\begin{array}{r}\ldots \ldots \\
\ldots \ldots . \\
\ldots \ldots . \\
\ldots 0.1 \\
0.1 \\
\ldots . . \\
0.4 \\
0.3 \\
0.9 \\
0.1 \\
46.4 \\
0.1 \\
39.8 \\
1.5 \\
7.4 \\
1.6 \\
\ldots \ldots . \\
\cdots \ldots .9 \\
1.9 \\
\cdots \ldots . \\
\cdots 0.3 \\
0.1\end{array}$ & $\begin{array}{r}1 \\
6 \\
2 \\
1 \\
\ldots \\
\cdots \\
4 \\
3 \\
715 \\
2 \\
275 \\
2 \\
179 \\
10 \\
158 \\
22 \\
1 \\
1 \\
1 \\
1 \\
1 \\
1 \\
1\end{array}$ & $\begin{array}{r}0.1 \\
0.9 \\
0.3 \\
0.1 \\
\ldots \ldots . \\
\cdots 0.6 \\
0.6 \\
0.4 \\
\cdots 2.2 \\
0.3 \\
40.1 \\
0.3 \\
26.2 \\
1.5 \\
23.1 \\
3.2 \\
0.1 \\
0.1 \\
0.1 \\
0.1 \\
0.1 \\
0.1 \\
0.1\end{array}$ \\
\hline All.......... & 733 & 100.0 & 687 & 100.0 \\
\hline
\end{tabular}


TABLE 4

SAMPLE DISTRIBUTION OF PURCHASES*

(In Each of 3 Periods, by Community Size, by Type of Outlet)

\begin{tabular}{|c|c|c|c|c|c|c|}
\hline & \multicolumn{3}{|c|}{ FaIR Trade } & \multicolumn{3}{|c|}{ Non-FaIR Trade } \\
\hline & $63 \hat{k}$ & 47 ह & $27 k$ & 638 & $47 \xi$ & $27 k$ \\
\hline Period 1: & 114 & 131 & 135 & 88 & 169 & 166 \\
\hline Cities: & 72 & 66 & 40 & 54 & 87 & 60 \\
\hline $\begin{array}{l}\text { Food stores.... } \\
\text { Drug stores... } \\
\text { Other........ }\end{array}$ & $\begin{array}{l}13 \\
49 \\
10\end{array}$ & $\begin{array}{l}26 \\
18 \\
22\end{array}$ & $\begin{array}{l}14 \\
14 \\
12\end{array}$ & $\begin{array}{r}30 \\
19 \\
5\end{array}$ & $\begin{array}{l}51 \\
24 \\
12\end{array}$ & $\begin{array}{r}46 \\
8 \\
6\end{array}$ \\
\hline
\end{tabular}

Towns and rural: $\quad \begin{array}{lllllll}42 & 65 & 95 & 34 & 82 & 106\end{array}$

$\begin{array}{lllllll}\text { Food stores.... } & 8 & 36 & 44 & 15 & 48 & 75\end{array}$

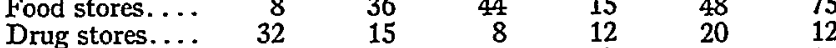

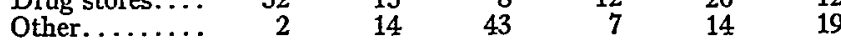

\begin{tabular}{|c|c|c|c|c|c|c|}
\hline Period 2: & 347 & 396 & 443 & 244 & 479 & 482 \\
\hline Cities: & 221 & 182 & 149 & 154 & 257 & 149 \\
\hline $\begin{array}{l}\text { Food stores..... } \\
\text { Drug stores.... } \\
\text { Other......... }\end{array}$ & $\begin{array}{l}92 \\
85 \\
44\end{array}$ & $\begin{array}{l}88 \\
68 \\
26\end{array}$ & $\begin{array}{l}91 \\
31 \\
27\end{array}$ & $\begin{array}{l}85 \\
48 \\
21\end{array}$ & $\begin{array}{r}161 \\
65 \\
31\end{array}$ & $\begin{array}{r}106 \\
23 \\
20\end{array}$ \\
\hline Towns and rural: & 126 & 214 & 294 & 90 & 222 & 233 \\
\hline $\begin{array}{l}\text { Food stores.... } \\
\text { Drug stores.... } \\
\text { Other........ }\end{array}$ & $\begin{array}{l}36 \\
64 \\
26\end{array}$ & $\begin{array}{r}124 \\
56 \\
34\end{array}$ & $\begin{array}{r}143 \\
32 \\
119\end{array}$ & $\begin{array}{r}61 \\
20 \\
9\end{array}$ & $\begin{array}{r}165 \\
30 \\
27\end{array}$ & $\begin{array}{r}166 \\
23 \\
44\end{array}$ \\
\hline Period 3: & 209 & 203 & 155 & 156 & 226 & 139 \\
\hline Cities: & 144 & 97 & 52 & 95 & 101 & 42 \\
\hline $\begin{array}{l}\text { Food stores.... } \\
\text { Drug stores..... } \\
\text { Other......... }\end{array}$ & $\begin{array}{l}64 \\
45 \\
35\end{array}$ & $\begin{array}{l}51 \\
33 \\
13\end{array}$ & $\begin{array}{r}36 \\
11 \\
5\end{array}$ & $\begin{array}{l}46 \\
27 \\
22\end{array}$ & $\begin{array}{l}74 \\
11 \\
16\end{array}$ & $\begin{array}{r}35 \\
4 \\
3\end{array}$ \\
\hline Towns and rural: & 65 & 106 & 103 & 61 & 125 & 97 \\
\hline $\begin{array}{l}\text { Food stores.... } \\
\text { Drug stores.... } \\
\text { Other........ }\end{array}$ & $\begin{array}{l}28 \\
24 \\
13\end{array}$ & $\begin{array}{l}71 \\
13 \\
22\end{array}$ & $\begin{array}{l}60 \\
10 \\
33\end{array}$ & $\begin{array}{r}38 \\
14 \\
9\end{array}$ & $\begin{array}{l}91 \\
13 \\
21\end{array}$ & $\begin{array}{r}60 \\
7 \\
30\end{array}$ \\
\hline All Periods: & 670 & 730 & 733 & 488 & 874 & 687 \\
\hline Cities: & 437 & 345 & 241 & 303 & 445 & 251 \\
\hline $\begin{array}{l}\text { Food stores.... } \\
\text { Drug stores.... } \\
\text { Other........ }\end{array}$ & $\begin{array}{r}169 \\
179 \\
89\end{array}$ & $\begin{array}{r}165 \\
119 \\
61\end{array}$ & $\begin{array}{r}141 \\
56 \\
44\end{array}$ & $\begin{array}{r}161 \\
94 \\
48\end{array}$ & $\begin{array}{r}286 \\
100 \\
59\end{array}$ & $\begin{array}{r}187 \\
35 \\
29\end{array}$ \\
\hline Towns and rural: & 233 & 385 & 492 & 185 & 429 & 436 \\
\hline $\begin{array}{l}\text { Food stores.... } \\
\text { Drug stores.... } \\
\text { Other......... }\end{array}$ & $\begin{array}{r}72 \\
120 \\
41\end{array}$ & $\begin{array}{r}231 \\
84 \\
70\end{array}$ & $\begin{array}{r}247 \\
50 \\
195\end{array}$ & $\begin{array}{r}114 \\
46 \\
25\end{array}$ & $\begin{array}{r}304 \\
63 \\
62\end{array}$ & $\begin{array}{r}301 \\
42 \\
93\end{array}$ \\
\hline
\end{tabular}

* Purchases at special deal prices authorized by the manufacturers have been excluded. (See Appendix Table 5 for effect of this exclusion.) 


\section{TABLE 5}

TOOTHPASTE PURCHASES EXCLUDED FROM THE STUDY BECAUSE OF AUTHORIZED EXCEPTIONS AS "SPECIAL DEATS"

\begin{tabular}{|c|c|c|c|c|c|c|}
\hline & \multicolumn{2}{|c|}{$63 \notin S z 2 z$} & \multicolumn{2}{|c|}{$47 \xi$ SuzE } & \multicolumn{2}{|c|}{ 27\& Srze } \\
\hline & $\begin{array}{l}\text { Fair- } \\
\text { Trade } \\
\text { States }\end{array}$ & $\begin{array}{l}\text { Non-Fair- } \\
\text { Trade } \\
\text { States }\end{array}$ & $\begin{array}{l}\text { Fair- } \\
\text { Trade } \\
\text { States }\end{array}$ & $\begin{array}{l}\text { Non-Fair- } \\
\text { Trade } \\
\text { States }\end{array}$ & $\begin{array}{l}\text { Fair- } \\
\text { Trade } \\
\text { States }\end{array}$ & $\begin{array}{c}\text { Non-Fair- } \\
\text { Trade } \\
\text { States }\end{array}$ \\
\hline No. of "deal" sales-cities. . & 0 & 11 & 28 & 99 & 21 & 6 \\
\hline $\begin{array}{c}\text { No. of "deal" sales-towns } \\
\text { and rural.............. }\end{array}$ & $\mathbf{0}$ & 1 & 30 & 58 & 8 & 0 \\
\hline Total "deal" sales.... & $\mathbf{0}$ & 12 & 58 & 157 & 29 & 6 \\
\hline $\begin{array}{c}\text { Aver. price on "deal" sales } \\
\text {-cities............... }\end{array}$ & $\ldots \ldots$ & $42.9 \notin$ & $34.1 \&$ & 32.18 & 17.68 & $15.5 \&$ \\
\hline $\begin{array}{c}\text { Aver. price on "deal" sales } \\
\text { - towns and rural. ..... }\end{array}$ & . & $59.0 \&$ & $34.5 f$ & $33.5 \&$ & $15.5 \notin$ & \\
\hline Aver. price all "deal" sales. & & $44.3 \notin$ & $34.3 \xi$ & $32.6 \&$ & $17.0 \%$ & $15.5 \&$ \\
\hline
\end{tabular}

TABLE 6

AVERAge Prices PaId For TOOTHPASTES IN PARTICULAR FAIR-TRADE AND NoN-FAIR-Trade STATES

All Size Places (Unweighted),

All Outlets, by Periods

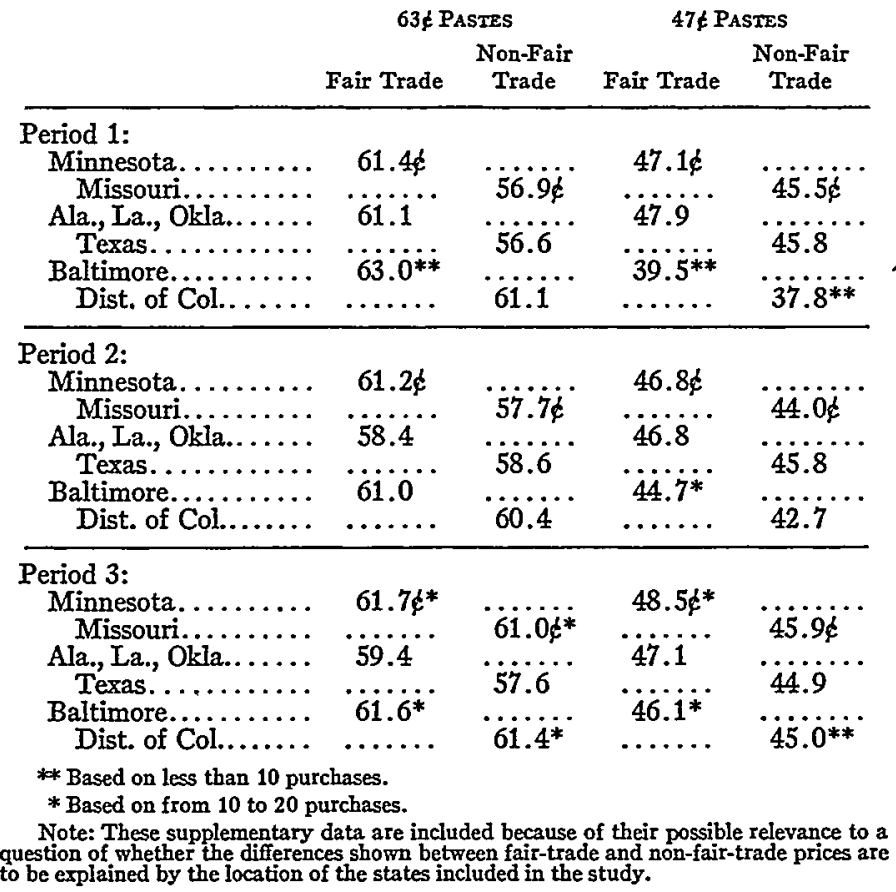


TABLE 7

DisTribution OF NATIONAL CONSUMER PANEL FAMMIES WITHIN SELECTED NON-FAIR-AND

FAIR-TRADE AREAS

\begin{tabular}{|c|c|c|}
\hline & $\begin{array}{c}\text { Texas and } \\
\text { Missouri } \\
\text { (Non-Fair } \\
\text { Trade) } \\
100 \%\end{array}$ & $\begin{array}{c}\text { Alabama, } \\
\text { Louisiana, } \\
\text { Minnesota, } \\
\text { Oklahoma } \\
\text { (Fair Trade) } \\
\text { 100\% }\end{array}$ \\
\hline $\begin{array}{l}\text { Area total........................ } \\
\text { City size: }\end{array}$ & $100 \%$ & \\
\hline Farm and $-2,500 \ldots \ldots \ldots \ldots \ldots$ & 39 & 40 \\
\hline $2,500-50,000$ & 16 & 18 \\
\hline $50,000-250,000 \ldots$ & 9 & 10 \\
\hline 250,000 plus. ...... & 36 & 32 \\
\hline $\begin{array}{l}\text { Age of housewife: } \\
-35 \text { years. . . . }\end{array}$ & 20 & 20 \\
\hline $35-44$ years. . . & 27 & 27 \\
\hline $45-54$ years.......... & 12 & 13 \\
\hline 55 and over. . . . . . & 41 & 40 \\
\hline Family size: & & \\
\hline 1 and 2 members.... & 37 & 32 \\
\hline $\mathbf{3}$ members.$\ldots \ldots \ldots \ldots \ldots \ldots$ & 22 & 22 \\
\hline 4 and 5 members. . . . . . . . . . & 29 & 31 \\
\hline 6 plus. $\ldots \ldots \ldots \ldots \ldots \ldots \ldots$ & 12 & 15 \\
\hline Education of aduli head: & & \\
\hline Grade School........ & 56 & 52 \\
\hline High School................ & 29 & 30 \\
\hline College...................... & 15 & 17 \\
\hline Occupation of adull head: & & \\
\hline Professional and executive. . . . . . & 20 & 18 \\
\hline Clerical and service. . . . . . . . & 17 & 21 \\
\hline Skilled labor.. $\ldots \ldots \ldots \ldots \ldots \ldots$ & 18 & 14 \\
\hline Unskilled. . . . . . . . . . . & 17 & 16 \\
\hline Farmer.................. & 15 & 17 \\
\hline Other. . . . . W $\ldots \ldots \ldots \ldots$ & 13 & 14 \\
\hline Children by age groups: & & \\
\hline No children. $\ldots \ldots \ldots \ldots \ldots \ldots$ & 46 & 45 \\
\hline 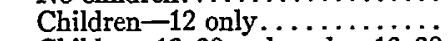 & 25 & 28 \\
\hline $\begin{array}{l}\text { Children } 13-20 \text { only, plus } 13-20 \\
\text { and }-6 \text { or } 6-12 \ldots \ldots \ldots \ldots \ldots \ldots\end{array}$ & 25 & 22 \\
\hline Children in all 3 age groups $(-6$, & 0 & 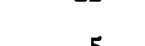 \\
\hline $\begin{array}{l}6-12,12-20) \ldots \ldots \ldots \\
\text { Tolal family income: }\end{array}$ & 4 & 5 \\
\hline$-\$ 3,000 \ldots \ldots$ & 37 & 40 \\
\hline$\$ 3,000-\$ 6,000 \ldots \ldots$ & $\begin{array}{l}48 \\
15\end{array}$ & $\begin{array}{l}43 \\
17\end{array}$ \\
\hline
\end{tabular}


TABLE 8

FaIR-Trade-Non-Fatr-Trade Comparisons

\begin{tabular}{|c|c|c|c|c|c|c|c|c|}
\hline PERTod & $\begin{array}{c}\text { Cosasonity } \\
\text { SrzE }\end{array}$ & OutLet & $\begin{array}{l}\text { Aver. } \\
\text { Price } \\
\text { Higher }\end{array}$ & $\begin{array}{c}\text { Aver. } \\
\text { Price } \\
\text { Higher }\end{array}$ & $\begin{array}{l}\text { Aver. } \\
\text { Price } \\
\text { Higher }\end{array}$ & $\begin{array}{c}\text { Aver. } \\
\text { Price } \\
\text { Higher }\end{array}$ & $\begin{array}{l}\text { Aver. } \\
\text { Price } \\
\text { Higher }\end{array}$ & $\begin{array}{l}\text { Aver. } \\
\text { Price } \\
\text { Higher }\end{array}$ \\
\hline \multirow[t]{6}{*}{$1 . .}$. & Cities & Food & $x$ & . & $\mathrm{x}$ & .. & $x$ & . \\
\hline & & Drug & $\mathbf{x}$ & .. & $\begin{array}{lll}\mathbf{x} & & \end{array}$ & .. & .. & $\mathrm{x}$ \\
\hline & & Other & $\mathrm{x}$ & .. & $\mathrm{x}$ & .. & .. & $\mathrm{x}$ \\
\hline & Towns and rural & Food & $x$ & .. & $x$ & .. & .. & $\mathrm{x}$ \\
\hline & & Drug & $\mathrm{x}$ & .. & $x$ & -. & $x$ & . \\
\hline & & Other & $x$ & $\cdots$ & $\mathrm{x}$ & $\cdots$ & $x$ & .. \\
\hline \multirow{5}{*}{$2 \ldots \ldots$} & Cities & Food & $\mathrm{x}$ & $\cdots$ & $\mathrm{x}$ & . & $\cdots$ & $\mathrm{x}$ \\
\hline & & Drug & $\mathrm{x}$ & $\cdots$ & $x$ & $\cdots$ & $\cdots$ & $x$ \\
\hline & & Other & $\mathrm{x}$ & $\cdots$ & $x$ & -. & $\mathrm{x}$ & $\because$ \\
\hline & Towns and rural & Food & $x$ & .. & $x$ & . & .. & $\mathrm{x}$ \\
\hline & & Drug & $\bar{x}$ & $\cdot \cdot$ & $x$ & $\cdots$ & $\ddot{x}$ & $x$ \\
\hline \multirow{6}{*}{ 3..... } & Cities & Food & $\begin{array}{l}x \\
x\end{array}$ & $\cdots$ & $\begin{array}{l}x \\
x\end{array}$ & $\begin{array}{l}\cdots \\
\cdots\end{array}$ & $\begin{array}{l}x \\
.\end{array}$ & $\ddot{x}$ \\
\hline & & Drug & $x$ & . & $\mathrm{x}$ & .. & $x$ & . \\
\hline & & Other & $\mathrm{x}$ & .. & $\mathrm{x}$ & .. & . & $\mathbf{x}$ \\
\hline & Towns and rural & Food & $x$ & . & $\mathrm{x}$ & .. & $x$ & .. \\
\hline & & Drug & .. & $\mathrm{x}$ & $\mathrm{x}$ & $\because$ & $x$ & $\because$ \\
\hline & & Other & $\cdots$ & $x$ & 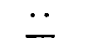 & $\mathbf{x}$ & $\ddot{-}$ & $\mathbf{x}$ \\
\hline \multicolumn{2}{|c|}{ Totals... } & $\ldots \ldots$ & 16 & 2 & 17 & 1 & 8 & 10 \\
\hline
\end{tabular}

TABLE 9

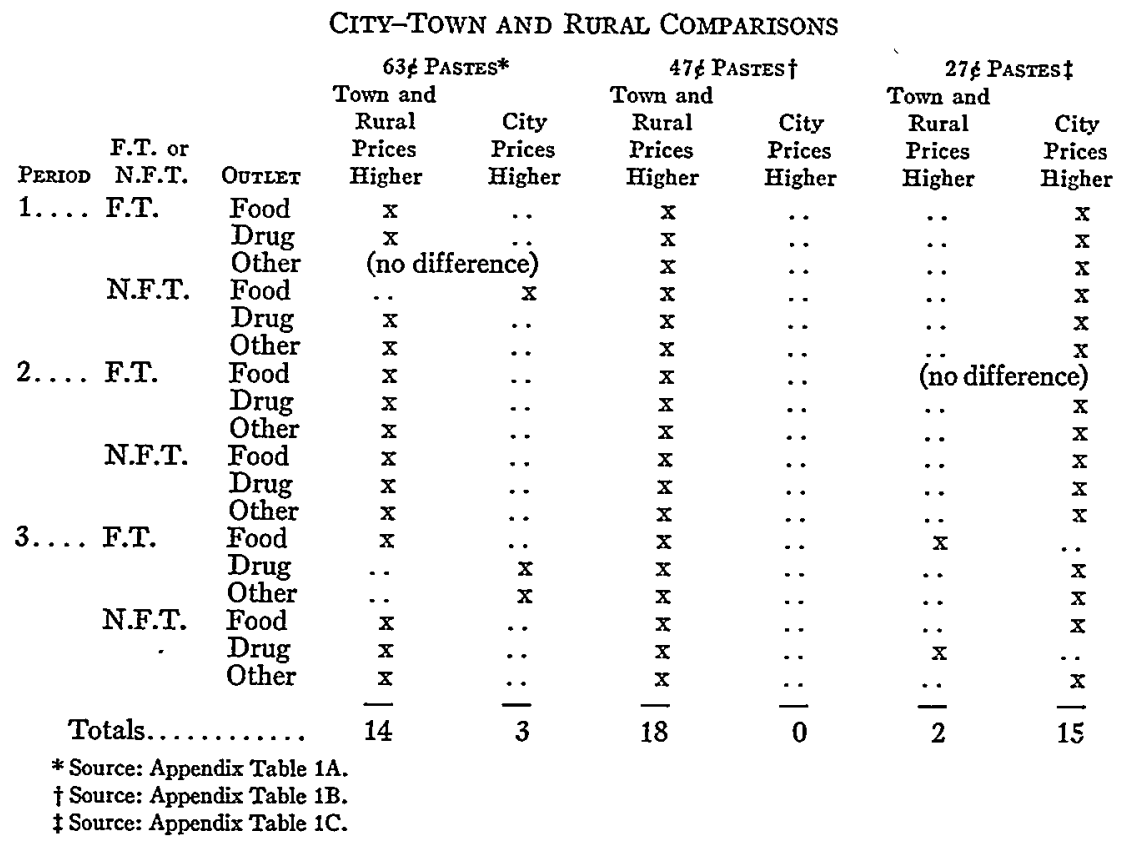


TABLE 10A

\section{DRUG STORE-FOOD STORE COMPARISONS}

\begin{tabular}{|c|c|c|c|c|c|c|}
\hline & \multicolumn{2}{|c|}{$63 \xi$ SIZE* } & \multicolumn{2}{|c|}{ 47 \& SIZE $f$} & \multicolumn{2}{|c|}{$27 \dot{\text { Size } \ddagger}$} \\
\hline & $\begin{array}{l}\text { Aver. } \\
\text { Price } \\
\text { in Food } \\
\text { Stores } \\
\text { Higher }\end{array}$ & $\begin{array}{c}\text { Aver. } \\
\text { Price } \\
\text { in Drug } \\
\text { Stores } \\
\text { Higher }\end{array}$ & $\begin{array}{c}\text { Aver. } \\
\text { Price } \\
\text { in Food } \\
\text { Stores } \\
\text { Higher }\end{array}$ & $\begin{array}{c}\text { Aver. } \\
\text { Price } \\
\text { in Drug } \\
\text { Stores } \\
\text { Higher }\end{array}$ & $\begin{array}{l}\text { Aver. } \\
\text { Price } \\
\text { in Food } \\
\text { Stores } \\
\text { Higher }\end{array}$ & $\begin{array}{l}\text { Aver. } \\
\text { Price } \\
\text { in Drug } \\
\text { Stores } \\
\text { Higher }\end{array}$ \\
\hline \multicolumn{7}{|l|}{ Cities: } \\
\hline Period 1 F.T......... & $\mathbf{x}$ & . & $x$ & .. & $\bar{x}$ & $\cdots$ \\
\hline Period 2 F.T.T........ & $\mathrm{x}$ & .. & $\because$ & $\mathrm{x}$ & $\cdots$ & $x$ \\
\hline Period 2 F.T......... & $\ddot{x}$ & $\begin{array}{c}x \\
. .\end{array}$ & $\begin{array}{l}x \\
x\end{array}$ & $\because$ & $\ddot{x}$ & $\mathbf{x}$ \\
\hline Period 3 F.T......... & $\mathbf{x}$ & $\because$ & $\cdots$ & $\ddot{x}$ & $x$ & $\ddot{0} \quad r$ \\
\hline $\begin{array}{r}\text { N.F.T........ } \\
\text { (subtotals) } \ldots \ldots \ldots\end{array}$ & (4) & $\begin{array}{l}x \\
(2)\end{array}$ & $\begin{array}{l}x \\
(4) \\
(4)\end{array}$ & (2) & $\underset{(4)}{x}$ & (2) \\
\hline \multicolumn{7}{|l|}{ Towns and rural: } \\
\hline Period 1 F.T......... & $\mathbf{x}$ & .. & $\mathbf{x}$ & . & $\mathbf{x}$ & .. \\
\hline N.F.T...... & . & $x$ & $\cdots$ & $\mathbf{x}$ & $\mathbf{x}$ & .. \\
\hline Period 2 F.T......... & .. & $\mathbf{x}$ & $x$ & $\cdots$ & & \\
\hline N.F.T.. .... & $x$ & $\cdots$ & $\mathbf{x}$ & .. & \multicolumn{2}{|c|}{ (no difference) } \\
\hline Period 3 F.T......... & $\mathbf{x}$ & .. & \multirow{2}{*}{\multicolumn{2}{|c|}{$\ddot{\text { Gindifference) }} \mathbf{x}$}} & $x$ & $\ldots$ \\
\hline N.F.T....... & $x$ & & & & $\mathrm{x}$ & \\
\hline (subtotals)....... & (4) & (2) & (3) & (2) & (5) & (0) \\
\hline Totals............ & 8 & 4 & 7 & 4 & 9 & 2 \\
\hline T Source: Appenatix Table & & & & & & \\
\hline
\end{tabular}

TABLE 10B

DRUG STORE-OTHER (NON-FOOD) COMIPARISONS

\begin{tabular}{|c|c|c|c|c|c|c|}
\hline & \multicolumn{2}{|c|}{$63 £$ SIzE* } & \multicolumn{2}{|c|}{$47 \xi$ SrzE $\dagger$} & \multicolumn{2}{|c|}{$27 \xi$ SIzE $\ddagger$} \\
\hline & $\begin{array}{l}\text { Aver. } \\
\text { Price } \\
\text { in Drug } \\
\text { Stores } \\
\text { Higher }\end{array}$ & $\begin{array}{c}\text { Aver. } \\
\text { Price } \\
\text { in Other } \\
\text { Stores } \\
\text { Higher }\end{array}$ & $\begin{array}{c}\text { Aver. } \\
\text { Price } \\
\text { in Drug } \\
\text { Stores } \\
\text { Higher }\end{array}$ & $\begin{array}{l}\text { Aver. } \\
\text { Price } \\
\text { in Other } \\
\text { Stores } \\
\text { Higher }\end{array}$ & $\begin{array}{l}\text { Aver. } \\
\text { Price } \\
\text { in Drug } \\
\text { Stores } \\
\text { Higher }\end{array}$ & $\begin{array}{l}\text { Aver. } \\
\text { Price } \\
\text { in Other } \\
\text { Stores } \\
\text { Higher }\end{array}$ \\
\hline \multicolumn{7}{|l|}{ Cities: } \\
\hline Period 1 F.T......... & $\ddot{x}$ & $x$ & $\because$ & $x$ & $\mathbf{x}$ & .. \\
\hline Period 2 F.T........... & $\begin{array}{l}x \\
x\end{array}$ & $\because$ & $\begin{array}{l}x \\
x\end{array}$ & $\because$ & $\mathrm{x}$ & $\ddot{x}$ \\
\hline N.F.T...... & $\bar{x}$ & .. & $\begin{array}{l}x \\
x\end{array}$ & $\ddot{0}$ & $\ddot{x}$ & \\
\hline $\begin{array}{l}\text { Period } 3 \text { F.T........... } \\
\text { N.F.T....... }\end{array}$ & $\mathrm{x}$ & .. & $x$ & .. & $x$ & .. \\
\hline $\begin{array}{r}\text { N.F.1......... } \\
\text { (subtotals)........ }\end{array}$ & $\begin{array}{c}x \\
(5)\end{array}$ & (1) & (4) & $\begin{array}{c}x \\
(2)\end{array}$ & (4) & $\begin{array}{c}x \\
(2)\end{array}$ \\
\hline $\begin{array}{l}\text { Towns and rural: } \\
\text { Period } 1 \mathrm{~F} . \mathrm{T} . . . \ldots \ldots\end{array}$ & & $\mathrm{x}$ & & 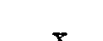 & & \\
\hline N.F.T....... & $\ddot{x}$ & $\boldsymbol{\lambda}$ & $\ddot{x}$ & . & $\cdots$ & $\begin{array}{l}x \\
x\end{array}$ \\
\hline Period 2 F.T.......... & & .. & $x$ & :. & $\ddot{0} \quad$ r & $\frac{x}{x}$ \\
\hline N.F.T....... & \multicolumn{2}{|c|}{ (no difference) } & & $\mathbf{x}$ & \multirow{2}{*}{\multicolumn{2}{|c|}{$\stackrel{x}{\text { (no difference) }}$}} \\
\hline Period 3 F.T......... & $\mathbf{x}$ & $\cdots$ & $\mathbf{x}$ & .. & & \\
\hline $\begin{array}{r}\text { N.F.T........ } \\
\text { (subtotals)........ }\end{array}$ & (3) & $\begin{array}{c}x \\
(2)\end{array}$ & (3) & $\begin{array}{l}x \\
(3)\end{array}$ & (i) & $\begin{array}{c}x \\
(4)\end{array}$ \\
\hline Totals............ & 8 & 3 & 7 & 5 & 5 & 6 \\
\hline
\end{tabular}


TABLE 10C

FOOD STORE-OTHER (NON-DRUG) COMPARISONS

\begin{tabular}{|c|c|c|c|c|c|c|}
\hline & \multicolumn{2}{|c|}{ 63\& SizE* } & \multicolumn{2}{|c|}{$47 \&$ SIZE $\dagger$} & \multicolumn{2}{|c|}{$27 \&$ SIzE $\ddagger$} \\
\hline & $\begin{array}{l}\text { Aver. } \\
\text { Price } \\
\text { in Food } \\
\text { Stores } \\
\text { Hugher }\end{array}$ & $\begin{array}{l}\text { Aver. } \\
\text { Price } \\
\text { in Other } \\
\text { Stores } \\
\text { Higher }\end{array}$ & $\begin{array}{c}\text { Aver. } \\
\text { Price } \\
\text { in Food } \\
\text { Stores } \\
\text { Higher }\end{array}$ & $\begin{array}{l}\text { Aver. } \\
\text { Price } \\
\text { in Other } \\
\text { Stores } \\
\text { Higher }\end{array}$ & $\begin{array}{l}\text { Aver. } \\
\text { Price } \\
\text { in Food } \\
\text { Stores } \\
\text { Higher }\end{array}$ & $\begin{array}{l}\text { Aver. } \\
\text { Price } \\
\text { in Other } \\
\text { Stores } \\
\text { Higher }\end{array}$ \\
\hline Cities: & & & & & & \\
\hline Period 1 F.T.... & $\cdots$ & $\mathrm{x}$ & $\mathbf{x}$ & $\cdots$ & $x$ & \\
\hline N.F.T.... & $x$ & 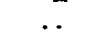 & $\mathrm{x}$ & .. & $\cdots$ & $\mathbf{x}$ \\
\hline Period 2 F.T........ & .. & $\mathbf{x}$ & $\mathrm{x}$ & .. & .. & $\mathbf{x}$ \\
\hline N.F.T....... & $\mathbf{x}$ & .. & $\mathbf{x}$ & .. & $\mathrm{x}$ & \\
\hline Period 3 F.T......... & $\mathrm{x}$ & .. & $\mathrm{x}$ & .. & .. & $\mathbf{x}$ \\
\hline $\begin{array}{r}\text { N.F.T........ } \\
\text { (subtotals) }\end{array}$ & $x$ & & $x$ & & (7) & $x$ \\
\hline $\begin{array}{l}\text { (subtotals)......... } \\
\text { Towns and rural: }\end{array}$ & (4) & (2) & (6) & (0) & (2) & (4) \\
\hline $\begin{array}{l}\text { Towns and rural: } \\
\text { Period } 1 \text { F.T.... }\end{array}$ & & & & & & \\
\hline Feriod 1 N.F.T........ & $x$ & $\ddot{r}$ & & $\mathrm{x}$ & $x$ & .. \\
\hline Period 2 F.T.......... & $\ddot{x}$ & $\therefore$ & $\frac{x}{x}$ & $\begin{array}{l}\cdots \\
\ldots\end{array}$ & $\begin{array}{l}x \\
x\end{array}$ & $\ddot{0}$ \\
\hline N.F.T..... & $x$ & .. & $\ldots$ & $x$ & $\bar{x}$ & $\ddot{.}$ \\
\hline Period 3 F.T........ & $x$ & .. & $x$ & .. & $x$ & .. \\
\hline $\begin{array}{c}N . F .1 . . \cdots \\
\text { (subtotals)......... }\end{array}$ & (4) & $\begin{array}{c}x \\
(2) \\
2\end{array}$ & (3) & $\begin{array}{c}x \\
(3) \\
(3)\end{array}$ & (5) & $\begin{array}{l}x \\
(1) \\
(1)\end{array}$ \\
\hline Totals............ & 8 & 4 & 9 & 3 & 7 & 5 \\
\hline
\end{tabular}

TABLE 11A

EFFecT of Schwegmann CASE ON PRICES IN FAIR-TRADE

AND NON-FAIR-TRADE STATES

(Period 1-Period 2 Comparisons in Fair-Trade States)

\begin{tabular}{|c|c|c|c|c|c|c|}
\hline & \multicolumn{2}{|c|}{$63 \xi$ SizE* } & \multicolumn{2}{|c|}{ 47 $\dot{\xi}$ SrzE $\dagger$} & \multicolumn{2}{|c|}{ 27 $\delta$ Size $f$} \\
\hline & $\begin{array}{c}\text { Aver. } \\
\text { Price } \\
\text { in Period } 1 \\
\text { Higher }\end{array}$ & $\begin{array}{l}\text { Aver. } \\
\text { Price } \\
\text { in Period } 2 \\
\text { Higher }\end{array}$ & $\begin{array}{l}\text { Aver. } \\
\text { Price } \\
\text { in Period } 1 \\
\text { Higher }\end{array}$ & $\begin{array}{c}\text { Aver. } \\
\text { Price } \\
\text { in Period } 2 \\
\text { Higher }\end{array}$ & $\begin{array}{l}\text { Aver. } \\
\text { Price } \\
\text { in Period } 1 \\
\text { Higher }\end{array}$ & $\begin{array}{l}\text { Aver. } \\
\text { Price } \\
\text { in Period } \\
\text { Higher }\end{array}$ \\
\hline F.T. cities: & & & & & & \\
\hline Food stores. . . . . . . & $\mathbf{x}$ & . & $\mathbf{x}$ & . & $\mathbf{x}$ & .. \\
\hline Drug stores......... & $\mathbf{x}$ & .. & $x$ & .. & $\mathbf{x}$ & . \\
\hline Other............. & $\mathbf{x}$ & .. & $\mathbf{x}$ & .. & .. & $\mathbf{x}$ \\
\hline F.T. towns and rural: & & & & & & \\
\hline Food stores.......... & $x$ & .. & $\mathbf{x}$ & .. & .. & $\mathbf{x}$ \\
\hline Drug stores. . . . . . . & $\mathbf{x}$ & $\cdots$ & $\mathbf{x}$ & $\cdots$ & $\cdots$ & $\mathbf{x}$ \\
\hline Other.......... & $\mathbf{x}$ & .. & $\mathbf{x}$ & . & .. & $\mathbf{x}$ \\
\hline Totals...... & 6 & $\mathbf{0}$ & 6 & 0 & 2 & 4 \\
\hline
\end{tabular}




\section{TABLE 11A-Continued}

(Period 1-Period 2 Comparisons in Non-Fair-Trade States)

\begin{tabular}{|c|c|c|c|c|c|c|}
\hline & \multicolumn{2}{|c|}{$63 \&$ SIzE* } & \multicolumn{2}{|c|}{ 47દ́ SrzE $\nmid$} & \multicolumn{2}{|c|}{ 27\& SIZE } \\
\hline & $\begin{array}{l}\text { Aver. } \\
\text { Price } \\
\text { in Period } 1 \\
\text { Higher }\end{array}$ & $\begin{array}{l}\text { Aver. } \\
\text { Price } \\
\text { in Period } 2 \\
\text { Higher }\end{array}$ & $\begin{array}{l}\text { Aver. } \\
\text { Price } \\
\text { in Period } 1 \\
\text { Higher }\end{array}$ & $\begin{array}{l}\text { Aver. } \\
\text { Price } \\
\text { in Period } 2 \\
\text { Higher }\end{array}$ & $\begin{array}{l}\text { Aver. } \\
\text { Price } \\
\text { in Period } 1 \\
\text { Higher }\end{array}$ & $\begin{array}{c}\text { Aver. } \\
\text { Price } \\
\text { in Period } 2 \\
\text { Higher }\end{array}$ \\
\hline \multicolumn{7}{|l|}{ N.F.T. cities: } \\
\hline Food stores. . . . . . . & $\mathbf{x}$ & $\ldots$ & $\cdots$ & $\mathbf{x}$ & $\cdots$ & $\mathbf{x}$ \\
\hline Drug stores. ........ & $\mathbf{x}$ & .. & $x$ & .. & $x$ & $\therefore$ \\
\hline Other stores......... & . & $\mathbf{x}$ & $x$ & $\cdots$ & $\mathrm{x}$ & $\cdots$ \\
\hline N.F.T. towns and rural: & & & & & & \\
\hline Food stores. . . . . . & $\cdots$ & $\mathbf{x}$ & $\mathrm{x}$ & $\cdots$ & $\cdots$ & $\therefore x$ \\
\hline Drug stores. . . . . . . & $x$ & . & $x$ & . & $\ldots$ & $\mathbf{x}$ \\
\hline Other stores........ & $\cdots$ & $x$ & $\cdots$ & $\mathbf{x}$ & $\mathbf{x}$ & $\cdots$ \\
\hline Totals.......... & 3 & 3 & 4 & 2 & 3 & 3 \\
\hline $\begin{array}{l}\text { * Source: Appendix Table } \\
\text { † Source: Appendix Table } \\
\text { † Source: Appendix Table }\end{array}$ & & & & & - & \\
\hline
\end{tabular}

TABLE 11B

\section{EFfect of McGuIRe ACT on Prices IN Fatr-Trade \\ AND Non-FaIR-TRAdE STATES \\ (Period 2-Period 3 Comparisons in Fair-Trade States)}

\begin{tabular}{|c|c|c|c|c|c|c|}
\hline & \multicolumn{2}{|c|}{$63 \&$ SIZE* } & \multicolumn{2}{|c|}{ 47\& SIZE $\dagger$} & \multicolumn{2}{|c|}{ 27\& SIZE } \\
\hline & $\begin{array}{l}\text { Aver. } \\
\text { Price in } \\
\text { Period } 3 \\
\text { Higher }\end{array}$ & $\begin{array}{l}\text { Aver. } \\
\text { Price in } \\
\text { Period } 2 \\
\text { Higher }\end{array}$ & $\begin{array}{l}\text { Aver. } \\
\text { Price in } \\
\text { Period } 3 \\
\text { Higher }\end{array}$ & $\begin{array}{l}\text { Aver. } \\
\text { Price in } \\
\text { Period } 2 \\
\text { Higher }\end{array}$ & $\begin{array}{c}\text { Aver. } \\
\text { Price in } \\
\text { Period } 3 \\
\text { Higher }\end{array}$ & $\begin{array}{l}\text { Aver. } \\
\text { Price in } \\
\text { Period } 2 \\
\text { Higher }\end{array}$ \\
\hline F.T. cities: & & & & & & \\
\hline Food stores. . . . . . . & $x$ & .. & $\cdots$ & $\mathrm{x}$ & $x$ & $\cdots$ \\
\hline Drug stores. . . . . . . & $\mathbf{x}$ & $\cdots$ & $x$ & . & $x$ & .. \\
\hline $\begin{array}{l}\text { Other. } \\
\text { F.T. towns and rural: }\end{array}$ & $x$ & $\cdots$ & . & $x$ & $\mathbf{x}$ & $\cdots$ \\
\hline Food stores. ......... & $x$ & $\cdots$ & . & $\mathbf{x}$ & $x$ & $\cdots$ \\
\hline Drug stores. . . . . . . & . & $x$ & . & $\mathbf{x}$ & $\mathbf{x}$ & .. \\
\hline Other............ & $\cdots$ & $\mathbf{x}$ & . & $x$ & $\mathbf{x}$ & $\cdots$ \\
\hline Totals........... & 4 & 2 & 1 & 5 & 6 & 0 \\
\hline
\end{tabular}

(Period 2-Period 3 Comparisons in Non-Fair-Trade States)

\begin{tabular}{|c|c|c|c|c|c|c|}
\hline & \multicolumn{2}{|c|}{ 63\& SIaE* } & \multicolumn{2}{|c|}{ 47\& Srax $\dagger$} & \multicolumn{2}{|c|}{ 27 $\not$ Size $\ddagger$} \\
\hline & $\begin{array}{l}\text { Aver. } \\
\text { Price in } \\
\text { Period } 3 \\
\text { Higher }\end{array}$ & $\begin{array}{l}\text { Aver. } \\
\text { Price in } \\
\text { Period } 2 \\
\text { Higher }\end{array}$ & $\begin{array}{c}\text { Aver. } \\
\text { Price in } \\
\text { Period } 3 \\
\text { Higher }\end{array}$ & $\begin{array}{l}\text { Aver. } \\
\text { Price in } \\
\text { Period } 2 \\
\text { Higher }\end{array}$ & $\begin{array}{c}\text { Aver. } \\
\text { Price in } \\
\text { Périod } 3 \\
\text { Higher }\end{array}$ & $\begin{array}{l}\text { Aver. } \\
\text { Price in } \\
\text { Period } 2 \\
\text { Higher }\end{array}$ \\
\hline N.F.T. cities: & & & & & & \\
\hline Food stores. . . . . . . . & $x$ & $\cdots$ & $\cdots$ & $x$ & $\boldsymbol{x}$ & $\cdots$ \\
\hline Drug stores. . . . . . . & $\mathbf{x}$ & $\cdots$ & $\cdots$ & $\mathbf{x}$ & - & $x$ \\
\hline $\begin{array}{l}\text { Other. . . . . . . . . } \\
\text { N.F.T. towns and rural: }\end{array}$ & $x$ & $\cdots$ & $\boldsymbol{x}$ & $\cdots$ & $x$ & $\cdots$ \\
\hline Food stores........ & $\mathbf{x}$ & .. & $\cdots$ & $\mathrm{x}$ & $\mathbf{x}$ & . \\
\hline Drug stores. . . . . . . & $\mathbf{x}$ & $\cdots$ & $\mathbf{x}$ & $\cdots$ & . & $x$ \\
\hline Other.............. & $\mathbf{x}$ & $\cdots$ & $\cdots$ & $\mathrm{x}$ & $\mathbf{x}$ & . \\
\hline Totals. . & 6 & 0 & 2 & 4 & 4 & 2 \\
\hline
\end{tabular}

* Source: Appendix Table 1A.

† Source: Appendix Table 1B.

† Source: Appendix Table 1C. 